\title{
Artificial enzymes for the enantioselective Michael-type addition of thiols combining basic catalysis with two- and three-pronged oxyanion hole mimics
}

\author{
Luis Simón ${ }^{\mathrm{a}}$, Francisco M. Muñiz ${ }^{\mathrm{a}}$, Silvia Sáez ${ }^{\mathrm{a}}$, César Raposob ${ }^{\mathrm{b}}$, and Joaquín R. Morán ${ }^{\mathrm{a} *}$ \\ arganic Chemistry Department, Plaza de los Caídos, University of Salamanca, Salamanca, \\ E-37008, Spain. ${ }^{b}$ Mass Spectrometry Service, Plaza de los Caidos, University of Salamanca, \\ E-37008, Spain \\ E-mail:romoran@usal.es
}

Dedicated to Professor Joan Bosch on his $60^{\text {th }}$ birthday

\begin{abstract}
Artificial receptors with catalytic activities have been obtained for the enantioselective conjugated addition of ethanethiol to 5,6-dihydro-2-(H)-pyridinone. The xanthone-based receptors include an oxyanion hole structure combined with amine groups. Computer modeling studies have been performed on the reaction mechanism in an attempt to explain the catalytic activity.
\end{abstract}

Keywords: Enzyme like catalysts, molecular recognition, chiral catalyst, conjugated addition, oxyanion hole mimics, xanthone receptors

\section{Introduction}

The oxyanion hole structure in combination with basic groups is a common feature of many enzymes, such as proteases, lipases, esterases, dehalogenases, peroxidases and epoxide hydrolases, ${ }^{1}$ and can also be found in hydrolytic catalytic antibodies. ${ }^{2}$ The oxyanion hole consists of two or more H-bond donors (usually two peptide NHs from the backbone) oriented towards an oxygen atom of the substrate, which accumulates electron density in the transition state. The basic groups often found at the active sites of the enzyme (histidine, aspartate, glutamate, indole residues), or even a combination of several groups, as in catalytic triads, allow bifunctional catalysis in the enzymatic reaction mechanism when they are combined with the oxyanion hole structure. A good example of this bifunctional catalysis is that provided by enoyl-CoA hydratase, which catalyzes the conjugated addition of water to an unsaturated thioester. ${ }^{3} \mathrm{H}$-bond catalysis is 
performed by an oxyanion hole structure, and a glutamate residue is the element responsible for the proton transport from the nucleophile to the $\alpha$ carbon of the substrate.

Metal catalysts have shown an impressive development in the last two decades. Nevertheless, the toxicity of transition metals ${ }^{4}$ and their non-stability are drawbacks for their wide use in pharmaceutical and green chemistry processes. A wide variety of asymmetric organocatalysts, which covalently bind their substrates, have also been recently studied. ${ }^{5}$ Although many of these organocatalysts show high diastereo and enantioselectivities, chemical processes involving slow reactions (as the one studied here) require catalysts that, like natural enzymes, show high turnover and enhanced reaction rate. Recently, emphasis has been placed on artificial enzymes: organic molecules which supramolecular properties resemble enzymatic behaviour. $^{6}$

Wynberg and coworkers ${ }^{7}$ and Feringa and coworkers ${ }^{8}$ have reported the bifunctional catalysis of different alkaloids such as cinconidine in the 1,4 addition of thiols to cyclic $\alpha, \beta$ unsaturated carbonyl substrates. The proposed catalytic mechanism was based on stabilization of the negative charge on the carbonyl group of the substrate by an H-bond with the hydroxyl group of the alkaloid. As the second part of the reaction mechanism, the amine group of cinconidine played the role of a general basic catalyst.

The xanthone derivative receptor (figure 1) may be a good mimic of the oxyanion hole structure and has shown catalytic activity in reactions with charge accumulation in the carbonyl oxygen in their transition states. ${ }^{9}$ In the present work, we studied the ability of xanthone-based receptors that include amino groups as bifunctional catalysts in the Michael-type addition of ethanethiol to the 5,6-dihydro-2-(H)-pyridinone 1 (figure 1). The combination of an oxyanion hole with basic groups could afford good mimics of enoyl-CoA hydratase.

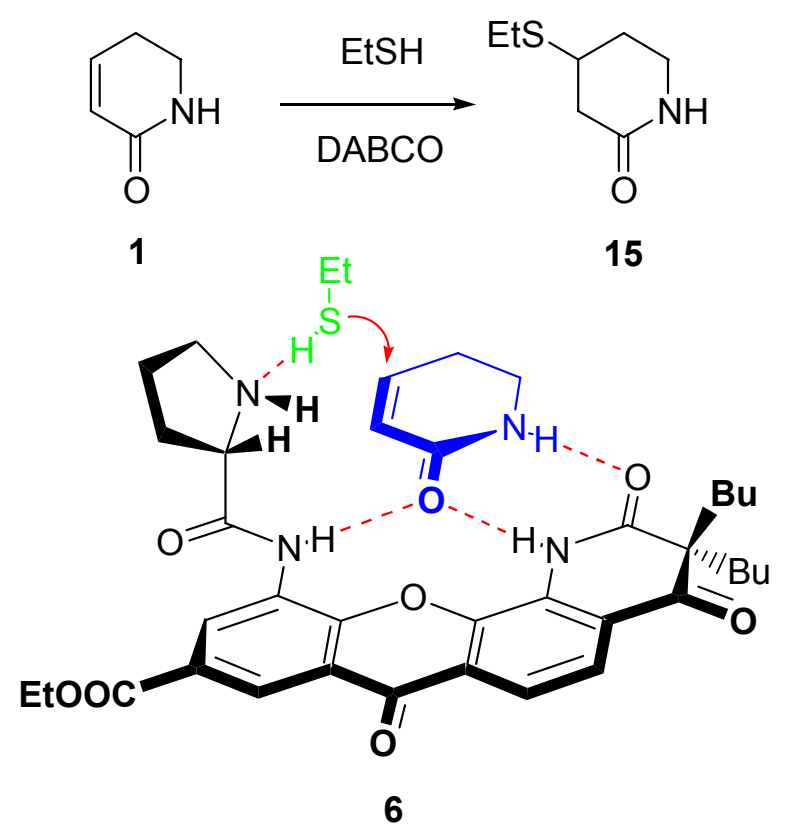

Figure 1. Addition of ethanethiol to lactam 1 and the catalytic complex between receptor $\mathbf{6}$ and lactam 1. 


\section{Results and Discussion}

\section{Reaction mechanism}

The reaction mechanism was first investigated using computational methods. The information obtained from the theoretical study will be used in the discussion of the catalytic activity of the different receptors.

The search for the transition-state structure was carried out using the GAUSSIAN $98 \mathrm{~W}^{10}$ program. The B3LYP density functional was employed with the Pople $6-31^{* *} \mathrm{G}$ basis set. Since we were interested in the reaction mechanism in non-polar solvents, benzene was included in the calculation, using the $\mathrm{PCM}^{11}$ solvation model to take into account the influence of the solvent in the reaction. To keep the calculations within a reasonable time scale, the model molecules $s$ trans acrolein, methyl mercaptan, ammonia, and trimethylamine were used. To analyze the stability of the transition-state structure of the different reaction mechanisms, energy barriers $(\Delta \mathrm{E})$, zero-point energy barriers ( $\Delta$ z.p.E), and free-energy barriers at $298.15 \mathrm{~K}(\Delta \mathrm{G})$ were calculated.

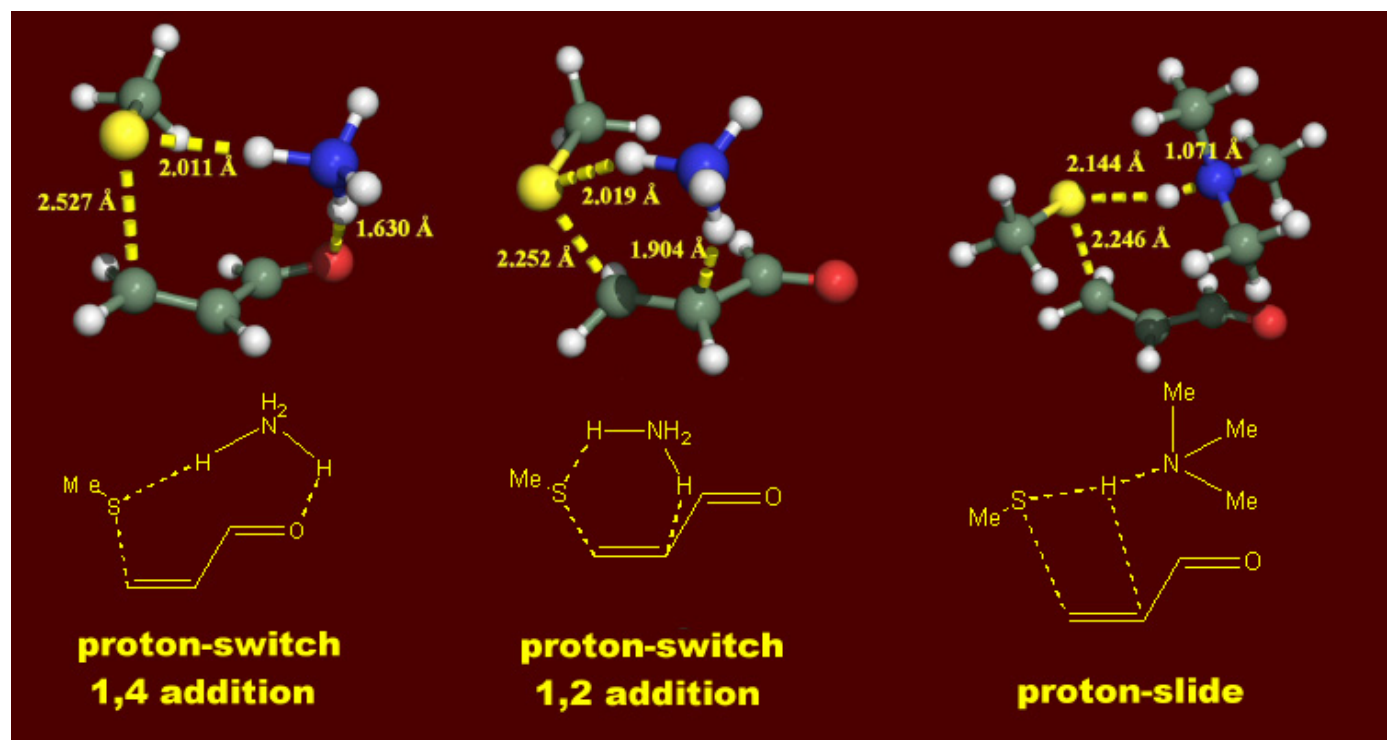

Figure 2. Transition-state structures found for the addition of methyl mercaptan to s-trans acrolein catalyzed by ammonia and trimethylamine.

For the reaction catalyzed by ammonia, it was possible to find two different transitionstates structures (figure 2) in which the basic group acted in a proton-transport process. Analysis of the imaginary frequency vibrational mode for the transition-state structures revealed that the addition and proton-transfer between thiol and ammonia, and between the auxiliary ammonia and acrolein, were concerted. This kind of mechanism, known as proton-switch, has already been described in literature for the addition of ammonia to acrolein catalyzed by water. ${ }^{12 a}$ More recently, it has also been proposed for $\mathrm{S}_{\mathrm{N}} 2$ reactions in water. ${ }^{12 \mathrm{~b}}$ The calculations showed that the 
1,4 addition mechanism (proton-transport to the carbonyl oxygen in the acrolein) was more energetically favored than the 1,2 addition (proton-transport to the $\alpha$ carbon).

Table 1. Energy barriers ( $\Delta E)$, zero-point energy barriers ( $\Delta z . p . E)$, free-energy barriers at 298.15 $\mathrm{K}(\Delta G)$, and CHELP-G charges on the acrolein oxygen atom for the calculated structures

\begin{tabular}{ccccc}
\hline $\begin{array}{c}\text { Transition- } \\
\text { state structure }\end{array}$ & $\Delta \mathrm{E}^{\mathrm{a}}$ & $\Delta \mathrm{z} . \mathrm{p} . \mathrm{E}^{\mathrm{a}}$ & $\Delta \mathrm{G}^{\mathrm{a}}$ & Charges $^{\mathrm{b}}$ \\
\hline $\begin{array}{c}\text { Proton-switch } \\
\text { 1,4 addition }\end{array}$ & 6.45 & 10.90 & 32.84 & -0.1754 \\
$\begin{array}{c}\text { Proton-switch } \\
\text { 1,2 addition }\end{array}$ & 13.35 & 17.52 & 38.59 & -0.1133 \\
Proton-slide & 10.45 & 16.09 & 39.42 & -0.1254 \\
\hline
\end{tabular}

${ }^{\mathrm{a}} \mathrm{kcal} / \mathrm{mol}$

${ }^{b}$ Difference with respect to the calculated s-trans acrolein charge in the carbonyl oxygen.

When ammonia was substituted by a tertiary amine, such as trimethylamine, we found a third mechanism in which a concerted addition and proton-transfer assisted by the auxiliary amine took place. Bruice and coworkers ${ }^{13}$ have suggested that this kind of mechanism, known as "proton-slide", could account for the fast aminolysis of quinoline-8-carboxylic acid aryl esters. By comparison of the energy barriers, it was deduced that tertiary amines are less effective in the catalysis than ammonia.

The wave functions of the optimized structures were used to calculate the CHELP-G charges, ${ }^{14}$ showing that, although our calculations supports a concerted mechanism instead of an ionic mechanism, negative charge on acrolein oxygen atom was incremented in the transitionstate. H-bonding of this oxygen atom should afford stabilization of the transition states, indicating that a combination of xanthone receptors and amino groups in the same structure may provide good catalysts.

\section{Catalytic activity of xanthone-based receptors}

The receptors studied in this work are shown in figure 3. To study their catalytic activities, the half-life times of the addition of ethanethiol to lactam 1 were measured. In the kinetic experiments, the initial concentration of the lactam 1 was $0.20 \mathrm{M}$ and the concentration of the catalyst was $0.02 \mathrm{M}$. Since the reaction was very slow, we used the nucleophile as solvent. The temperature was $305 \mathrm{~K}$, very close to the boiling point of the ethanethiol. To avoid solvent evaporation, the reaction samples were placed in sealed glass bulbs. The reaction mixture was recovered at different times and diluted 10 times in carbon tetrachloride to freeze the reaction. Then, the solvent and carbon tetrachloride were evaporated off at reduced pressure and at room temperature. 
Receptor 2, lacking the amino group, and DABCO were involved in an experiment to assess the relative importance of the inclusion of the amino group in the receptor structure. The relative association constants for the substrate with respect to receptor 2 were established by competitive titration using ${ }^{1} \mathrm{H}-\mathrm{NMR}\left(\mathrm{CDCl}_{3}\right)$. Portions of lactam 1 were added to a solution of a mixture of two receptors $(2 \mathrm{mg} / \mathrm{ml})$. Non-linear fitting of the evolution of the chemical shifts of the different receptors was performed. This experiment yielded the relative association constants. ${ }^{15}$ The results are summarized in table 2.<smiles>[R][Y4]([H])([H])c1cc(C(=O)OCC)cc2c(=O)c3ccc4c(c3oc12)NC(=O)C(C)(CC(C)(C)C)C4=O</smiles><smiles>[R]NC(=O)[C@H](N)c1ccccc1</smiles><smiles>[R]NC(=O)[C@@H]1CCCN1</smiles><smiles>[R]NC(=O)NCCN</smiles>

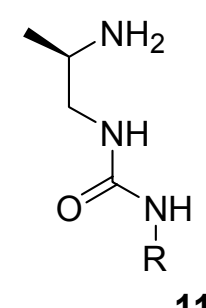

11<smiles>[Z]NC(=O)[C@@H]1CCCN1C</smiles><smiles>[R]NC(=O)N[C@H](c1ccccc1)[C@H](N)c1ccccc1</smiles>

12<smiles>[R]NC(=O)CN1CCCC1</smiles><smiles>[Z]ONC(=O)[C@H](N)C(C)C</smiles><smiles>[R8]NC(=O)C1CCCNC1</smiles><smiles>[R]NC(=O)N[C@@H]1CCCC[C@H]1N</smiles>

13<smiles>[R]NC(=O)C1CCCN(C)C1</smiles>

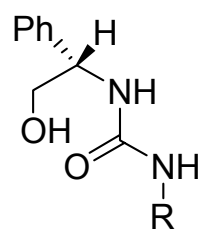

14

Figure 3. Structure of the compounds studied in this work.

To study the position of the basic group in the catalyst, we started with the preparation of $\alpha$ amino acid derivatives with different steric demands. The size of the side chain should affect the relative position of the basic catalytic group and hence receptors 3 (pyrrolidin-acetic acid derivative), 4 (valine derivative), 5 (phenyl-glycine derivative), 6 (proline derivative) and 7 (methyl-proline derivative) were tested. The catalytic activities of these compounds were very poor $\left(\mathrm{t}_{1 / 2} .: 472\right.$ hours for receptor $\mathbf{3}, 183$ hours for receptor $\mathbf{4}, 444$ hours for receptor $\mathbf{5}$, 77 hours for receptor 6). In fact some receptors were worse catalysts than the combination of the reference receptor 2 and DABCO ( $\mathrm{t}_{1 / 2}: 341$ hours). Nevertheless, this effect could be explained taking into account the small association constants in benzene in comparison with receptor $2\left(\mathrm{~K}_{\mathrm{rel}}: 0.017\right.$ for receptor 3, 0.065 for receptor 5), so the lack of complex formation might hinder the apparent catalysis. The exception was receptor $6\left(\mathrm{t}_{1 / 2}: 77\right.$ hours, $\left.\mathrm{K}_{\mathrm{rel}}=0.007\right)$, which showed a very low association constant and was a very good catalyst. The tertiary amine derivative receptors 
showed poorer catalytic activities. For example, receptor 7, with a structure similar to that of receptor 6 , showed the worst activity of the catalysts studied $\left(t_{1 / 2}: 1030\right.$ hours, $\left.\mathrm{K}_{\text {rel }}=0.022\right)$. This was not surprising because these receptors cannot catalyze the reaction by a proton-switch mechanism. As seen previously from the calculations, the proton-slide mechanism was less effective than the proton-switch mechanism. Despite this, the latter requires the presence of secondary or primary amines for its inclusion in the receptor structure.

CPK models suggested that one possibility for improving the catalytic activity of these receptors would be to place the basic group at the $\beta$ position of the chain. Owing to their structural rigidity, the nipecotic acid derivatives $\mathbf{8}$ and $\mathbf{9}$ were chosen to check this possibility. These receptors showed lower half-life times and, again, the tertiary amine receptor $9\left(\mathrm{t}_{1 / 2}=145\right.$ hours, $\left.\mathrm{K}_{\mathrm{rel}}=0.143\right)$ was worse than the receptor containing the secondary amine $8\left(\mathrm{t}_{1 / 2}=40\right.$ hours, $\mathrm{K}_{\mathrm{rel}}=0.006$ ).

Table 2. Half-life time, relative association constant $\left(\mathrm{K}_{\mathrm{rel}}\right)$ and enantiomeric ratio obtained with the receptors

\begin{tabular}{crcc}
\hline Catalyst & $\mathrm{t}_{1 / 2}{ }^{\mathrm{a}}$ & $\mathrm{K}_{\mathrm{rel}}^{\mathrm{b}}$ & $R / S \mathrm{ratio}^{\mathrm{c}}$ \\
\hline DABCO & 724 & & - \\
$\mathbf{2}+\mathrm{DABCO}$ & 341 & 1.000 & - \\
$\mathbf{3}$ & 472 & 0.017 & - \\
$\mathbf{4}$ & 183 & & $1.88: 1$ \\
$\mathbf{5}$ & 444 & 0.065 & $1.19: 1$ \\
$\mathbf{6}$ & 77 & 0.007 & $7.14: 1$ \\
$\mathbf{7}$ & 1030 & 0.022 & $1.04: 1$ \\
$\mathbf{8}$ & 40 & 0.006 & - \\
$\mathbf{9}$ & 145 & 0.143 & - \\
$\mathbf{1 0}$ & 60 & & - \\
$\mathbf{1 1}$ & 15 & & $0.78: 1$ \\
$\mathbf{1 2}$ & 691 & 0.935 & $1.28: 1$ \\
$\mathbf{1 3}$ & 6 & 0.071 & $1.05: 1$ \\
\hline
\end{tabular}

${ }^{\mathrm{a}}$ Hours

${ }^{\mathrm{b}}$ Referred to receptor 2 at $298 \mathrm{~K}$;

${ }^{\mathrm{c}}$ Measured by ${ }^{1} \mathrm{H}-\mathrm{NMR}$ signals integration of ethylthiolactam 15 with the chiral-shift compound 14.

Another possibility for placing the catalytic amine at a different position was to synthesize receptors including a urea group as a spacer. Thiourea like receptors prepared from ethylenediamine derivatives have been recently reported as good catalysts for the Michael addition of malonates to nitroolefins ${ }^{6 \mathrm{~d}}$ and for the cyanosylilation of ketenes. ${ }^{6 \mathrm{c}}$ Those precedents and the availability of enantiomerically pure ethylenediamine derivatives suggested the 
preparation of urea receptors $\mathbf{1 0}$ (ethylenediamine derivative), $\mathbf{1 1}$ (propylendiamine derivative), 12 (diphenyl-ethylenediamine derivative) and 13 (cyclohexylenediamine derivative). An additional advantage for a preliminary study is that small changes in the side chains were found to modify the position of the basic groups. These receptors showed some of the best catalytic activities found in this work. The exception was receptor 12, derived from 1,2diphenylethylenediamine, which showed very low catalytic activity $\left(\mathrm{t}_{1 / 2}=691\right.$ hours), even considering its large association constant $\left(\mathrm{K}_{\mathrm{rel}}=0.935\right)$. It is likely that the bulky phenyl groups would not allow this receptor to adopt a conformation in which the amino group could act by transporting the proton of ethanethiol. The cyclohexanediamine receptor $\mathbf{1 3}$ showed the lowest half-life time $\left(\mathrm{t}_{1 / 2}=6\right.$ hours, $\left.\mathrm{K}_{\text {rel }}=0.071\right)$, and a good catalytic activity: up to 120 times higher than DABCO. Its rigid cyclic structure very probably allowed it to fit in the transition state better than the acyclic receptors $10\left(\mathrm{t}_{1 / 2}=60\right.$ hours) and $\mathbf{1 1}\left(\mathrm{t}_{1 / 2}=15\right.$ hours $)$. This receptor allowed to obtain reaction product in $89 \%$ yield after one day (the product was purified from the mixture with the receptor by silica gel chromatography).

For the enantiomerically pure receptors, asymmetric induction of the reaction was also studied. A small amount of the chiral receptor 14 derived from phenylglycinol was able to split the $\mathrm{H}_{\alpha}{ }^{1} \mathrm{H}-\mathrm{NMR}$ signal of the enantiomeric ethylthiolactam $\mathbf{1 5}$ obtained in the reaction (figure 4).

As shown in figure 4 , the geometry of these two complexes must be very different. One of the diastereomeric complexes showed a strong interaction between the aromatic-shielding cone of receptor 14 and the axial $\mathrm{H}_{\alpha}$ of compound 15. This effect did not appear in the other complex. $\mathrm{H}_{\beta}$ irradiation was carried out to simplify the spectra. Integration by Gaussian deconvolution ${ }^{16}$ of the ${ }^{1} \mathrm{H}-\mathrm{NMR}$ signals afforded the enantiomeric ratios shown in table 2 when the reaction reached the half-life time. It was possible to determine the absolute configuration of the ethylthiolactam $\mathbf{1 5}$ by applying the octant rule ${ }^{17}$ to its observed circular dichroism.
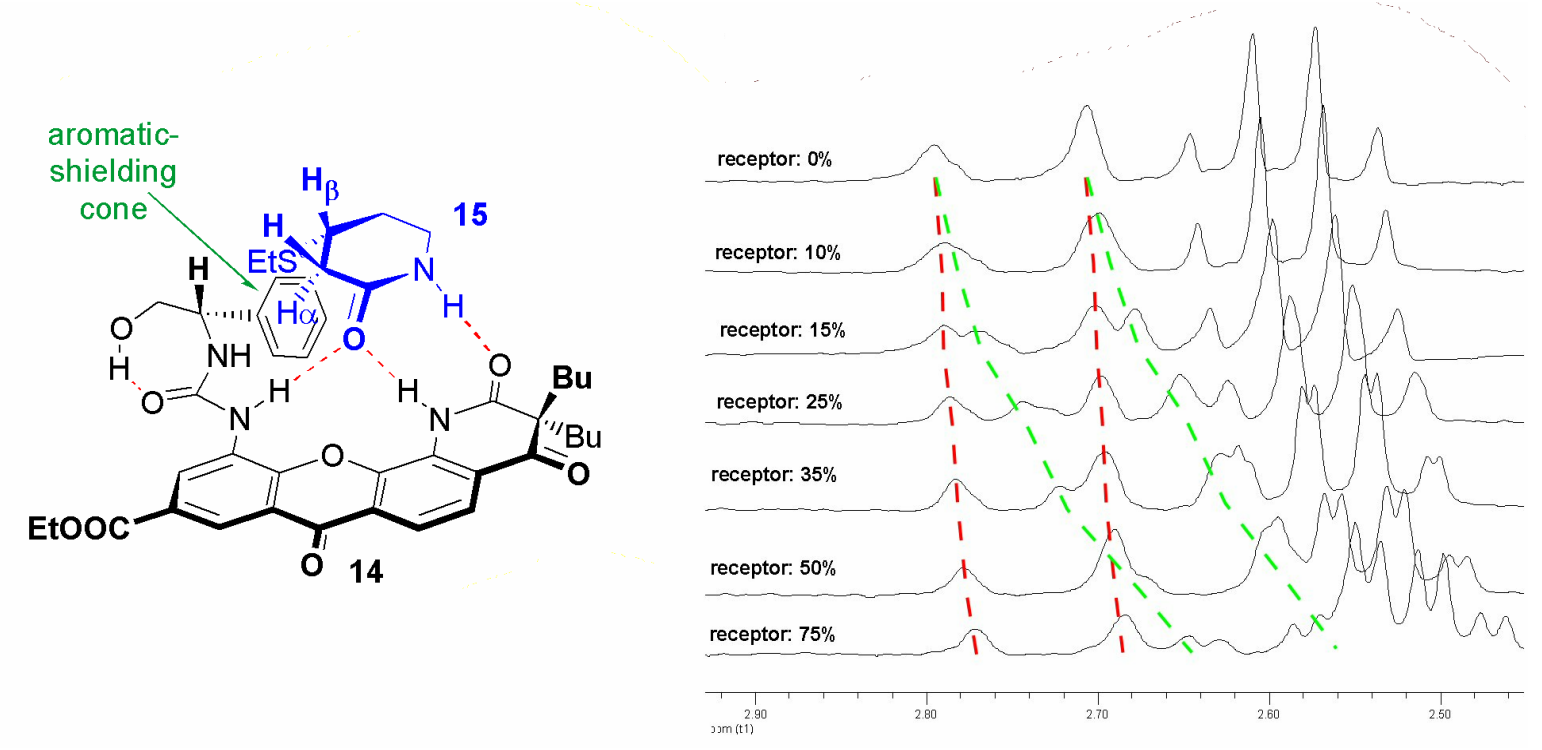

Figure 4. ${ }^{1} \mathrm{H}-\mathrm{NMR}$ signals of the axial hydrogen $\left(\mathrm{H}_{\alpha}\right)$ of the racemic ethylthiolactam 15 in the presence of different amounts of receptor 14 when $\mathrm{H}_{\beta}$ was irradiated. 
The highest enantiomeric $R / S$ ratio was obtained with the L-proline derivative receptor (L6). In an experiment in which the receptor derived from D-proline (D-6) was used, the $S$ enantiomer was obtained as the major product. This receptor also showed a constant asymmetric induction along time and did not vary when the amount of receptor was changed in the $10 \%$ to $2.5 \%$ range (table 3 ).

Table 3. Half-life time and enantiomeric ratio measured at different times for the reaction catalyzed by receptor (D-6) derived from D-proline

\begin{tabular}{crlrl}
\hline Catalyst & $\mathrm{t}_{1 / 2}$ & \multicolumn{3}{c}{$R / S$ ratio (time in hours) } \\
\hline $10 \%$ & 82 & $0.17: 1 \quad(43)$ & $0.14: 1 \quad(67)$ \\
& & $0.12: 1(139)$ & $0.21: 1(650)$ \\
$5.0 \%$ & 174 & $0.13: 1 \quad(43)$ & $0.12: 1(139)$ \\
& & $0.15: 1(191)$ & $0.18: 1(672)$ \\
$2.5 \%$ & \multirow{2}{*}{341} & $0.15: 1(139)$ & $0.25: 1(211)$ \\
& & $0.34: 1(488)$ & \\
\hline
\end{tabular}

Surprisingly, no asymmetric induction was observed for the reaction catalyzed by the receptor derived from the cyclohexanediamine 13, even though this receptor showed the best catalytic activity. In an attempt to explain this result, modelling studies on a model molecule using the $\mathrm{ONIOM}^{18}$ hybrid method with the Gaussian $98 \mathrm{~W}$ program were carried out. The partition of the molecule model in the high layer and the low layer for the ONIOM method is shown in figure 5. The high layer was treated with the B3LYP functional and the Pople 3-21G** basis set. The low layer was treated using the semiempirical PM3 level of theory, using molecular mechanics correction for the amide linkage.

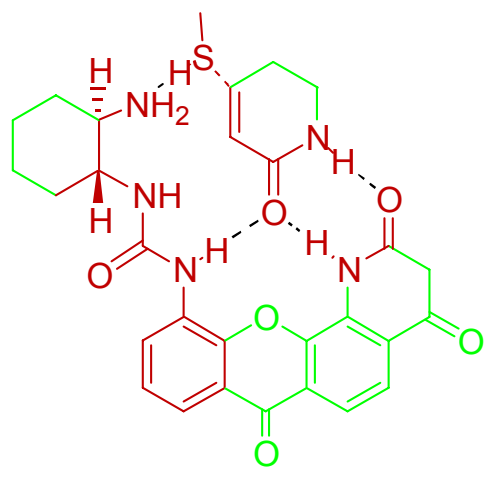

Figure 5. Partition of the model molecule in the high layer (red) and the low layer (green) used in the ONIOM calculations of the transition states with receptor 13.

Two different transition-state structures, each leading to the different enantiomers, were found (figure 6), showing that this model of receptor 13 can accommodate both transition states. 
The main difference between both diastereomeric transition-state structures was the dihedral angle between the cyclohexane and the urea. The structure leading to the $S$ enantiomer was only $0.36 \mathrm{kcal} / \mathrm{mol}$ more energetically favoured than the corresponding structure of the $R$ enantiomer. Owing to the size of the system, it was impossible to include solvation models or the vibrational contribution to the energy, which could have allowed us to obtain an even more similar value for the energy of both transition-state structures.

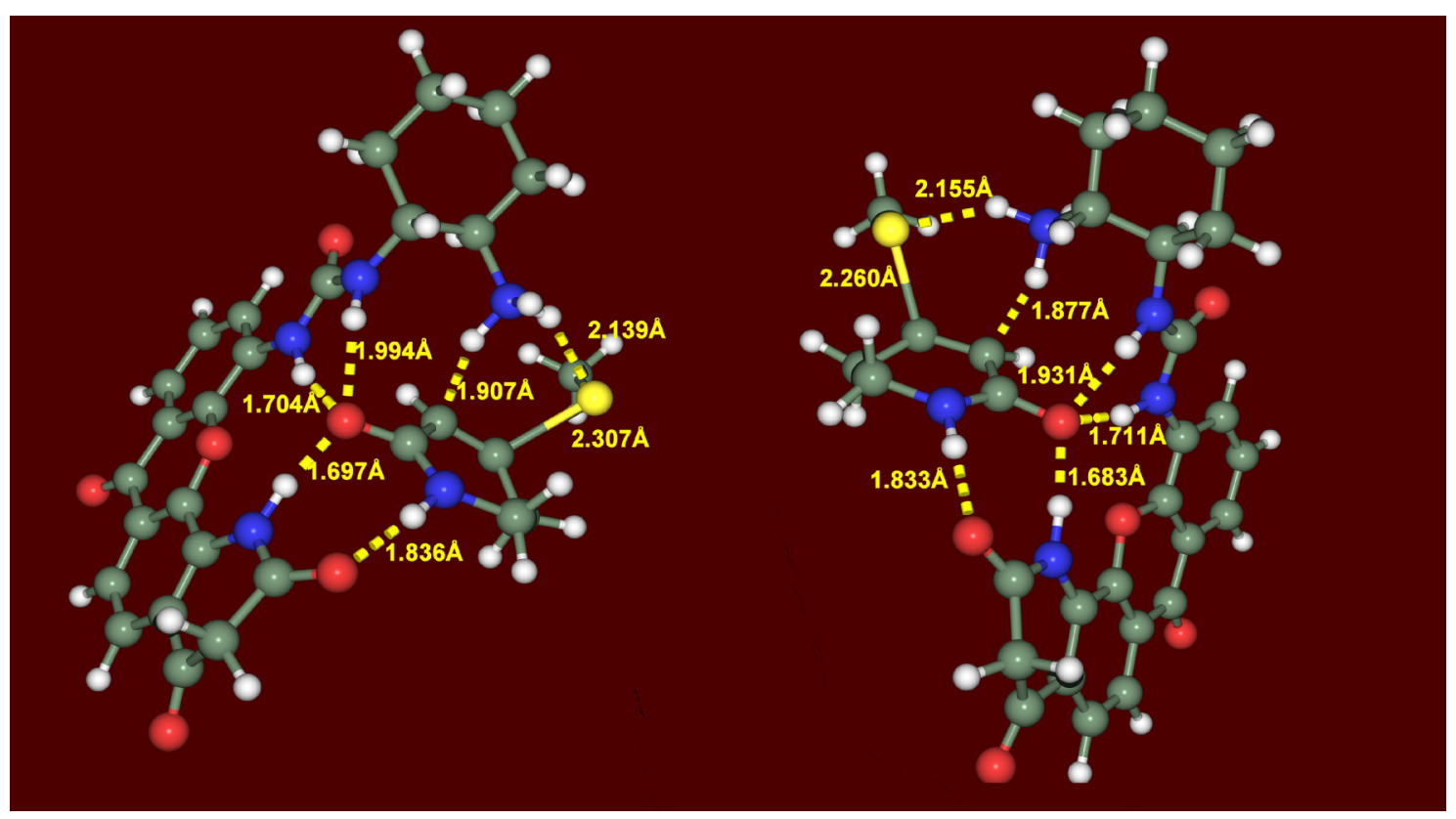

Figure 6. Optimized transition-state structures (ONIOM B3LYP/3-21G**:PM3MM), leading to the $S$ (left) and the $R$ (right) enantiomers, for the addition of the methyl mercaptan to the lactam $\mathbf{1}$ catalyzed with a model of receptor $\mathbf{1 3}$.

In both transition-state structures, the oxygen carbonyl group was linked by three H-bonds, instead of the two H-bonds of the oxyanion hole structures usually found in enzymes. The setting of these $3 \mathrm{H}$-bonds does not allow the transport of $\mathrm{H}$ atom to the carbonyl oxygen atom. Multiple H-bond stabilization of the transition state explains the high enhancement of reaction rate promoted by receptors $\mathbf{1 0}$ and $\mathbf{1 3}$ even though the reaction was carried out by a less favorable mechanism. The literature ${ }^{19}$ already contains examples of natural enzymes containing three $\mathrm{H}$ bonds in oxyanion hole structures (called a three-pronged oxyanion hole). The structure of the enzyme E. Coli thioesterase I/protease I/lysophospholipase L1 complexed with a diethylphosphono ester ${ }^{19}$ is available in the PDB database (PDB entry: $1 \mathrm{j} 00$ ). In figure 7, the transition-state structure that leads to the $S$ enantiomer has been overlaid with the X-Ray structure of the active center residues of this enzyme. The similarities between both molecular geometries suggest that the good catalytic activity of receptor $\mathbf{1 3}$ was not accidental. In the 
future, careful design of receptors containing three-H-bond oxyanion hole mimics and more rigid basic groups will probably allow improvements in both catalytic activities and chiral assistances.

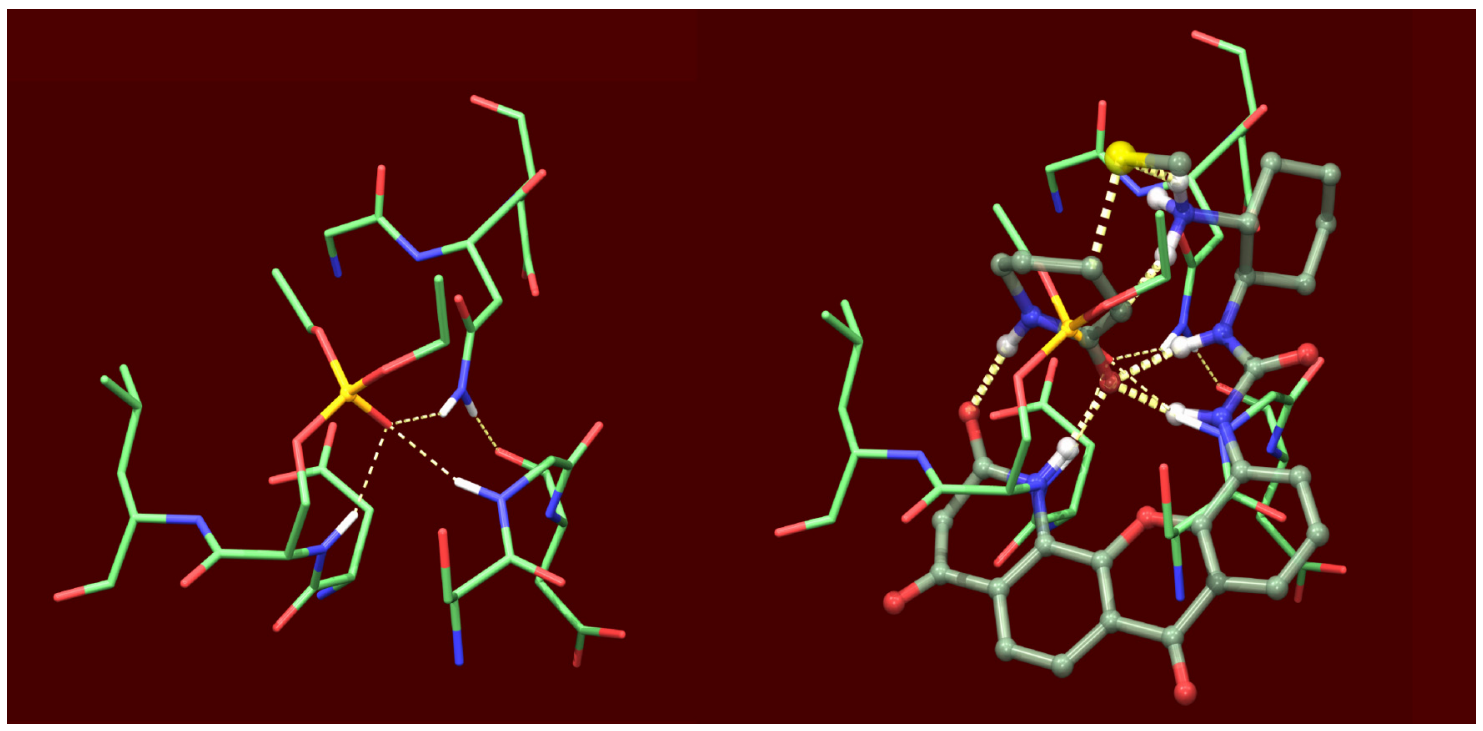

Figure 7. The structure obtained by X-Ray diffraction for the active site of E. Coli thioesterase I/protease I/lysophospholipase L1 complexed with the diethylphosphono ester. Right: the structure of the enzyme active site (wire model) was overlaid with the calculated structure for the transition state with receptor 13 (ball and stick model). Most hydrogen atoms have been omitted for clarity.

\section{Conclusions}

This work shows that the combination of a hydrogen -bond receptor an a basic amino group offer a promising way to achieve enzyme-like catalytic activity and to induce significant enantiomeric excesses of conjugated additions of thiols to unsaturated lactams.

\section{Experimental Section}

General Procedures. ${ }^{1} \mathrm{H}$ and ${ }^{13} \mathrm{C}-\mathrm{NMR}$ spectra were acquired on a Varian200 Mercury VX 2000 $200 \mathrm{MHz}$ spectrometer. Mass spectra were obtained with a Waters ZQ4000 quadrupole spectrometer, with positive electrospray ionization $(3.5 \mathrm{KV})$. IR spectra were recorded on a BOMEM MB-100FT IR spectrometer. Melting points were obtained with a Stuart Scientific SMP3 Apparatus. Elemental analysis were performed on a LECO CNHS932 analyzer. THF was distilled from sodium/benzophenone. 


\section{Compound characterization}

Preparation of compound 5,6-dihydro- $2 H$-pyridinone have been previously described. ${ }^{9 c}$

\section{Preparation of reaction product and recovery of the catalysts}

After a period of time enough to complete the reaction (3 days for receptor 13), the reaction mixtures were recovered from the sealed glass bulbs. The ethanethiol was evaporated off and the receptor can be separated from the reaction product by silica gel chromatography.

${ }^{1} \mathrm{H}-\mathrm{NMR}\left(\mathrm{CDCl}_{3}\right): 5.19$ (s, 1H), $3.53(\mathrm{~m}, 1 \mathrm{H}), 3.35(\mathrm{~m}, 1 \mathrm{H}), 3.17(\mathrm{~m}, 1 \mathrm{H}), 2.77$ (dd, J=17.6, $\mathrm{J}=4.9,1 \mathrm{H}), 2.60(\mathrm{c}, \mathrm{J}=7.4,2 \mathrm{H}), 2.37(\mathrm{dd}, \mathrm{J}=17.6, \mathrm{~J}=8.9,1 \mathrm{H}), 2.11(\mathrm{~m}, 1 \mathrm{H}), 1.81(\mathrm{~m}, 1 \mathrm{H}), 1,28(\mathrm{t}$, $\mathrm{J}=7.4,3 \mathrm{H}) ;{ }^{13} \mathrm{C}-\mathrm{NMR}\left(\mathrm{CDCl}_{3}\right): 170.3(\mathrm{C}), 39.2\left(\mathrm{CH}_{2}\right), 37.6\left(\mathrm{CH}_{2}\right), 36.2(\mathrm{CH}), 28.0\left(\mathrm{CH}_{2}\right), 23.8$ $\left(\mathrm{CH}_{2}\right), 14.1\left(\mathrm{CH}_{3}\right)$; $\mathrm{MS}(3.5 \mathrm{KV}, \mathrm{ESI}): 160\left(\mathrm{M}+\mathrm{H}^{+}\right), 182\left(\mathrm{M}+\mathrm{Na}^{+}\right), 198\left(\mathrm{M}+\mathrm{K}^{+}\right)$; I.R. $\lambda^{-1}$ (nujol): 3302, 3198, 1670, 1499, 1458, 1375, 1348, 1260, 1198, 1161, 1125, 1103, 1074, 974, 893, 858. Elem. Anal.calcld. for $\mathrm{C}_{7} \mathrm{H}_{13} \mathrm{NOS}$ : C 52.79, H 8.80, N 8.80, S 20.14; found: C 52.93, H 8.65, N 8.62, S 19.98 .

Preparation of receptor 2. Decanoyl chloride $(0.36 \mathrm{~g}, 2.1 \mathrm{mmol})$ was added to a solution of the xanthone amine derivative ${ }^{9 \mathrm{c}}$ shown in figure $8(1.0 \mathrm{~g}, 2.1 \mathrm{mmol})$ in dry THF $(10.0 \mathrm{ml})$. The reaction was heated to $50^{\circ} \mathrm{C}$ for 2 hours. Then, water $(2.0 \mathrm{ml})$ was added dropwise with magnetic stirring so that the desired compound 2 would precipitate. Receptor $\mathbf{2}$ was crystallized in a 9/1 ether/methylene chloride mixture yielding: $87 \%,(1.15 \mathrm{~g})$.

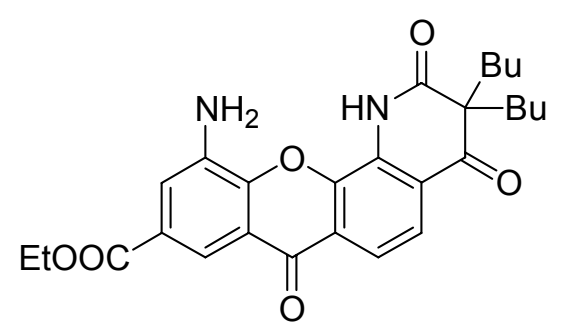

Figure 8. Structure of xanthone amine derivative.

Physical data for receptor 2. m.p.: $194-196^{\circ} \mathrm{C} ;{ }^{1} \mathrm{H}-\mathrm{NMR}\left(\mathrm{CDCl}_{3}\right): 9.25(\mathrm{~d}, 1 \mathrm{H}, \mathrm{J}=2.1 \mathrm{~Hz}), 8.82$ $(\mathrm{d}, 1 \mathrm{H}, \mathrm{J}=2.1 \mathrm{~Hz}), 8.14(\mathrm{~d}, 1 \mathrm{H}, \mathrm{J}=8.4 \mathrm{~Hz}), 7.97(\mathrm{~d}, 1 \mathrm{H}, \mathrm{J}=8.4 \mathrm{~Hz}), 4.47(\mathrm{q}, 2 \mathrm{H}, \mathrm{J}=7.1 \mathrm{~Hz}), 2.61$ $(\mathrm{t}, 2 \mathrm{H}, \mathrm{J}=7.3 \mathrm{~Hz}), 2.18-2.03(\mathrm{~m}, 2 \mathrm{H}), 1.94-1.80(\mathrm{~m}, 4 \mathrm{H}), 1.46(\mathrm{t}, 3 \mathrm{H}, \mathrm{J}=7.1 \mathrm{~Hz}), 1.47-1.33(\mathrm{~m}$, $12 \mathrm{H}), 1.30-1.17(\mathrm{~m}, 8 \mathrm{H}), 0.89(\mathrm{t}, 3 \mathrm{H}, \mathrm{J}=6.6 \mathrm{~Hz}), 0.79(\mathrm{t}, 6 \mathrm{H}, \mathrm{J}=6.4 \mathrm{~Hz}) ;{ }^{13} \mathrm{C}-\mathrm{NMR}\left(\mathrm{CDCl}_{3}\right)$ : 196.5 (C), 178.5 (C), 175.2 (C), 172.9 (C), 165.5 (C), 149.4 (C), 143.7 (C), 130.9 (CH), 130.5 (C), $128.6(\mathrm{C}), 126.5(\mathrm{C}), 124.5(\mathrm{CH}), 123.3(\mathrm{C}), 122.6(\mathrm{C}), 122.3(\mathrm{CH}), 122.0(\mathrm{C}), 117.3(\mathrm{CH})$, $62.9\left(\mathrm{CH}_{2}\right), 62.4(\mathrm{C}), 41.4\left(2 \mathrm{CH}_{2}\right), 37.6\left(\mathrm{CH}_{2}\right), 32.4\left(\mathrm{CH}_{2}\right), 30.2\left(5 \mathrm{CH}_{2}\right), 28.2\left(2 \mathrm{CH}_{2}\right), 26.0$ $\left(\mathrm{CH}_{2}\right), 23.6\left(2 \mathrm{CH}_{2}\right), 23.2\left(\mathrm{CH}_{2}\right), 14.9\left(\mathrm{CH}_{3}\right), 14.5\left(\mathrm{CH}_{3}\right), 14.0\left(2 \mathrm{CH}_{3}\right) ; \mathrm{MS}(3.5 \mathrm{KV}, \mathrm{ESI}): 633$ $\left(\mathrm{M}+\mathrm{H}^{+}\right), 655\left(\mathrm{M}+\mathrm{Na}^{+}\right), 671\left(\mathrm{M}+\mathrm{K}^{+}\right)$; I.R. $\lambda^{-1}$ (nujol): 3403, 3248, 1713, 1682, 1651, 1609, 1584 , $1537,1464,1377,1285,1246,1213,1099$, 1022. Elem. Anal.calcd. for $\mathrm{C}_{37} \mathrm{H}_{48} \mathrm{~N}_{2} \mathrm{O}_{7}$ : C 70.23, $\mathrm{H}$ 7.65, N 4.43; found: C 70.17, H 7.75, N 4.59. 
Preparation of receptor 3. The xanthone amine derivative $\mathrm{e}^{9 \mathrm{c}}(1.0 \mathrm{~g}, 2.1 \mathrm{mmol})$ was dissolved in dry THF (10.0 ml) and chloroacetyl chloride $(2.0 \mathrm{ml}, 25 \mathrm{mmol})$ was added. After 10 minutes at room temperature, water $(0.5 \mathrm{ml})$ was added dropwise and the reaction mixture was heated to $50^{\circ} \mathrm{C}$ for 2 minutes. The solvent was evaporated off at reduced pressure and the residue was dissolved in ethyl acetate $(20.0 \mathrm{ml})$ and washed with a $4 \% \mathrm{Na}_{2} \mathrm{CO}_{3}$ solution. The organic layer was recovered, dried with anhydrous $\mathrm{Na}_{2} \mathrm{SO}_{4}$, and the solvent was evaporated off to obtain the chloroacyl intermediate 16. Yield: $96 \%$, (1.11 g). This compound 16 (0.5 g, $0.9 \mathrm{mmol})$ was dissolved in ethanol $(15 \mathrm{ml})$ and pyrrolidine $(1 \mathrm{ml}, 12.0 \mathrm{mmol})$ was added. The reaction mixture was heated to $50^{\circ} \mathrm{C}$ for 1 hour. Water $(3.0 \mathrm{ml})$ was added dropwise with vigorous magnetic stirring to precipitate receptor 3 from the solution. Receptor 3 was crystallized in a $9 / 1$ ether/methylene chloride mixture yielding: $84 \%,(0.99 \mathrm{~g})$.

16. M.p.: $138-140^{\circ} \mathrm{C} ;{ }^{1} \mathrm{H}-\mathrm{NMR}\left(\mathrm{CDCl}_{3}\right): 9.15$ (d, $\left.1 \mathrm{H}, \mathrm{J}=2.0 \mathrm{~Hz}\right), 8.86(\mathrm{~d}, 1 \mathrm{H}, \mathrm{J}=2.0 \mathrm{~Hz}), 8.11$ $(\mathrm{d}, 1 \mathrm{H}, \mathrm{J}=8.4 \mathrm{~Hz}), 7.98(\mathrm{~d}, 1 \mathrm{H}, \mathrm{J}=8.4 \mathrm{~Hz}), 4.47(\mathrm{q}, 2 \mathrm{H}, \mathrm{J}=7.2 \mathrm{~Hz}), 4.39(\mathrm{~s}, 2 \mathrm{H}), 2.18-1.81(\mathrm{~m}$, $4 \mathrm{H}), 1.46(\mathrm{t}, 3 \mathrm{H}, \mathrm{J}=7.2 \mathrm{~Hz}), 1.18-0.84(\mathrm{~m}, 8 \mathrm{H}), 0.57(\mathrm{t}, 6 \mathrm{H}, \mathrm{J}=5.8 \mathrm{~Hz}) ;{ }^{13} \mathrm{C}-\mathrm{NMR}\left(\mathrm{CDCl}_{3}\right)$ : 195.9 (C), 177.0 (C), 174.2 (C), 164.7 (C), 164.1 (C), 148.6 (C), 143.0 (C), 138.8 (C), 130.5 (C), $128.6(\mathrm{CH}), 127.1(\mathrm{C}), 125.6(\mathrm{C}), 124.3(\mathrm{C}), 122.5(\mathrm{CH}), 121.7(\mathrm{CH}), 121.3(\mathrm{C}), 120.9(\mathrm{CH})$, $62.1(\mathrm{C}), 61.8\left(\mathrm{CH}_{2}\right), 43.3\left(\mathrm{CH}_{2}\right), 40.6\left(\mathrm{CH}_{2}\right), 27.2\left(\mathrm{CH}_{2}\right), 22.9\left(\mathrm{CH}_{2}\right), 14.165\left(\mathrm{CH}_{3}\right), 13.2\left(\mathrm{CH}_{3}\right)$; MS(3.5 KV, ESI): $555\left(\mathrm{M}+\mathrm{H}^{+}\right), 577\left(\mathrm{M}+\mathrm{Na}^{+}\right)$; I.R. $\lambda^{-1}$ (nujol): 3291, 1719, 1676, 1647, 1605, $1545,1458,1375,1281,1211,1101,1024$.

3. M.p.: $131-133^{\circ} \mathrm{C} ;{ }^{1} \mathrm{H}-\mathrm{NMR}\left(\mathrm{CDCl}_{3}-30 \% \mathrm{CD}_{3} \mathrm{OD}\right): 8.88(\mathrm{~d}, 1 \mathrm{H}, \mathrm{J}=1.9 \mathrm{~Hz}), 8.81(\mathrm{~d}, 1 \mathrm{H}, \mathrm{J}=$ $1.9 \mathrm{~Hz}), 8.03(\mathrm{~d}, 1 \mathrm{H}, \mathrm{J}=8.4 \mathrm{~Hz}), 7.94(\mathrm{~d}, 1 \mathrm{H}, \mathrm{J}=8.4 \mathrm{~Hz}), 4.44(\mathrm{q}, 2 \mathrm{H}, \mathrm{J}=7.1 \mathrm{~Hz}), 2.94(\mathrm{~s}, 2 \mathrm{H})$, 2.96-2.84 (m, 4H), 2.41-1.98 (m, 4H), 1.93-1.87 (m, 4H), $1.44(\mathrm{t}, 3 \mathrm{H}, \mathrm{J}=7.1 \mathrm{~Hz}), 1.21-1.04(\mathrm{~m}$, $8 \mathrm{H}), 0.73(\mathrm{t}, 6 \mathrm{H}, \mathrm{J}=6.4 \mathrm{~Hz}) ;{ }^{13} \mathrm{C}-\mathrm{NMR}\left(\mathrm{CDCl}_{3}\right): 197.1(\mathrm{C}), 176.2(\mathrm{C}), 175.0(\mathrm{C}), 164.8(\mathrm{C})$, $162.8(\mathrm{C}), 142.8(\mathrm{C}), 142.4(\mathrm{C}), 131.5(\mathrm{C}), 127.6(\mathrm{C}), 126.1(\mathrm{CH}), 125.4(\mathrm{C}), 123.4(\mathrm{C}), 122.3$ (C), $122.0(\mathrm{CH}), 121.5(\mathrm{C}), 119.7(\mathrm{CH}), 119.0(\mathrm{CH}), 62.8(\mathrm{C}), 61.7\left(\mathrm{CH}_{2}\right), 55.0\left(\mathrm{CH}_{2}\right), 39.7$ $\left(\mathrm{CH}_{2}\right), 39.6\left(\mathrm{CH}_{2}\right), 27.2\left(\mathrm{CH}_{2}\right), 23.9\left(\mathrm{CH}_{2}\right), 22.9\left(\mathrm{CH}_{2}\right), 14.3\left(\mathrm{CH}_{3}\right), 13.6\left(\mathrm{CH}_{3}\right)$; $\mathrm{MS}(3.5 \mathrm{KV}$, ESI): $590\left(\mathrm{M}+\mathrm{H}^{+}\right), 612\left(\mathrm{M}+\mathrm{Na}^{+}\right)$; I.R. $\lambda^{-1}$ (nujol): 3220, 1709, 1674, 1603, 1559, 1462, 1377 , $1348,1287,1246,1211,1101,1069$, 1026. Elem. Anal.calcld. for $\mathrm{C}_{33} \mathrm{H}_{39} \mathrm{~N}_{3} \mathrm{O}_{7}$ : C 67.22, $\mathrm{H} 6.67$, N 7.13; found: C 67.07, H 6.48, N 7.19.

Preparation of receptors 4 to 9. Amino acid chlorides were prepared from the corresponding amino acid. $\mathrm{PCl}_{5}$ (0.9 equivalents) was added to a suspension of the amino acid (1.0 g) in $\mathrm{CH}_{2} \mathrm{Cl}_{2}$ $(10.0 \mathrm{ml})$ with magnetic stirring and cooled externally to $-4^{\circ} \mathrm{C}$. When $\mathrm{PCl}_{5}$ crystals had completely dissolved, dry diethyl ether $(5.0 \mathrm{ml})$ was added. White crystals of the desired hydrochloride amino acid chlorides precipitated. The crystals were filtered under an argon atmosphere and washed several times with dry diethyl ether. Since a rapid hydrolysis took place, the crystals were stored under an argon atmosphere.

A large excess (5 equivalents) of amino acid chlorides was added to a solution of the xanthone amine derivative ${ }^{16}(1.0 \mathrm{~g}, 2.1 \mathrm{mmol})$ in dry THF $(10.0 \mathrm{ml})$ and the mixture was stirred for 10 minutes at room temperature. Then, water $(0.5 \mathrm{ml})$ was added and the reaction mixture was heated to $50^{\circ} \mathrm{C}$ for 2 minutes to hydrolyze the excess acid chloride. The solvent was 
evaporated off under vacuum and the solid residue was dissolved in ethyl acetate and washed with a $4 \% \mathrm{Na}_{2} \mathrm{CO}_{3}$ solution and water. The organic layer was recovered and the desired receptor was obtained after evaporation of the solvent under reduced pressure. The receptors were recrystallized from methanol/water. Yields with respect to xanthone amine derivative: receptor 4: $82 \%,(0.99 \mathrm{~g})$; receptor 5: 78\%, $(0.99 \mathrm{~g})$; receptor 6: 76\%, $(0.91 \mathrm{~g})$; receptor 7: $89 \%$, $(1.10 \mathrm{~g})$; receptor 8: 73\%, $(0.90 \mathrm{~g})$; receptor 9: 76\%, $(0.96 \mathrm{~g})$.

4. M.p.: $113-115^{\circ} \mathrm{C} ;[\alpha]_{\mathrm{D}}{ }^{20}=-19.7\left(c=1.13 \mathrm{CHCl}_{3}\right) ;{ }^{1} \mathrm{H}-\mathrm{NMR}\left(\mathrm{CDCl}_{3}\right): 9.27(\mathrm{~d}, 1 \mathrm{H}, \mathrm{J}=2.0 \mathrm{~Hz})$, $8.74(\mathrm{~d}, 1 \mathrm{H}, \mathrm{J}=2.0 \mathrm{~Hz}), 8.05(\mathrm{~d}, 1 \mathrm{H}, \mathrm{J}=8.4 \mathrm{~Hz}), 7.97(\mathrm{~d}, 1 \mathrm{H}, \mathrm{J}=8.4 \mathrm{~Hz}), 4.45(\mathrm{q}, 2 \mathrm{H}, \mathrm{J}=7.1$ $\mathrm{Hz}), 3.60(\mathrm{~d}, 1 \mathrm{H}, \mathrm{J}=3.4 \mathrm{~Hz}), 2.76-2.61(\mathrm{~m}, 1 \mathrm{H}), 2.15-1.99(\mathrm{~m}, 4 \mathrm{H}), 1.44(\mathrm{t}, 3 \mathrm{H}, \mathrm{J}=7.1 \mathrm{~Hz})$, 1.30-1.16 (m, 8H), $1.15(\mathrm{~d}, 3 \mathrm{H}, \mathrm{J}=7.0 \mathrm{~Hz}), 0.97$ (d, 3H, J = 7.0 Hz), $0.80(\mathrm{t}, 6 \mathrm{H}, \mathrm{J}=6.5 \mathrm{~Hz})$; ${ }^{13} \mathrm{C}-\mathrm{NMR}\left(\mathrm{CDCl}_{3}\right)$ : $196.5(\mathrm{C}), 174.6(\mathrm{C}), 173.5$ (C), 172.3 (C), $164.6(\mathrm{C}), 147.7$ (C), 142.2 (C),138.6 (C), $134.5(\mathrm{C}), 131.4(\mathrm{C}), 127.5(\mathrm{C}), 125.1(\mathrm{CH}), 122.5(\mathrm{C}), 122.2(\mathrm{CH}), 121.7(\mathrm{C})$, $121.0(\mathrm{CH}), 119.2(\mathrm{CH}), 62.7(\mathrm{C}), 61.4\left(\mathrm{CH}_{2}\right), 61.0(\mathrm{CH}), 39.0\left(\mathrm{CH}_{2}\right), 30.7(\mathrm{CH}), 26.9\left(\mathrm{CH}_{2}\right)$, $22.7\left(\mathrm{CH}_{2}\right), 19.5\left(\mathrm{CH}_{3}\right), 16.1\left(\mathrm{CH}_{3}\right), 14.1\left(\mathrm{CH}_{3}\right), 13.4\left(\mathrm{CH}_{3}\right)$; $\mathrm{MS}(3.5 \mathrm{KV}, \mathrm{ESI}): 578\left(\mathrm{M}+\mathrm{H}^{+}\right)$, $600\left(\mathrm{M}+\mathrm{Na}^{+}\right)$; I.R. $\lambda^{-1}$ (nujol): 3271, 1705, 1674, 1603, 1539, 1464, 1377, 1289, 1246, 1213, 1163, 1026. Elem. Anal.calcld. for $\mathrm{C}_{32} \mathrm{H}_{39} \mathrm{~N}_{3} \mathrm{O}_{7}$ : C 66.53, H 6.80, N 7.27; found: C 66.38, H 6.71, N 7.38.

5. M.p.: $122-124^{\circ} \mathrm{C} ;[\alpha]_{D}{ }^{20}=+39.7\left(c=0.75 \mathrm{CHCl}_{3}\right) ;{ }^{1} \mathrm{H}-\mathrm{NMR}\left(\mathrm{CDCl}_{3}\right): 9.24(\mathrm{~d}, 1 \mathrm{H}, \mathrm{J}=2.0 \mathrm{~Hz})$, $8.76(\mathrm{~d}, 1 \mathrm{H}, \mathrm{J}=2.0 \mathrm{~Hz}), 8.06(\mathrm{~d}, 1 \mathrm{H}, \mathrm{J}=8.4 \mathrm{~Hz}), 7.97(\mathrm{~d}, 1 \mathrm{H}, \mathrm{J}=8.4 \mathrm{~Hz}), 7.57-26(\mathrm{~m}, 5 \mathrm{H}), 4.86$ $(\mathrm{s}, 1 \mathrm{H}), 4.42(\mathrm{q}, 2 \mathrm{H}, \mathrm{J}=7.1 \mathrm{~Hz}), 2.13-1.91(\mathrm{~m}, 4 \mathrm{H}), 1.41(\mathrm{t}, 3 \mathrm{H}, \mathrm{J}=7.1 \mathrm{~Hz}), 1.32-1.05(\mathrm{~m}, 8 \mathrm{H})$, 0.80 (t, 6H, J = 6.7 Hz); ${ }^{13} \mathrm{C}-\mathrm{NMR}\left(\mathrm{CDCl}_{3}\right): 196.8(\mathrm{C}), 174.8$ (C), 173.7 (C), 171.1 (C), 164.7 (C), $147.8(\mathrm{C}), 142.2(\mathrm{C}), 139.7(\mathrm{C}), 135.5(\mathrm{C}), 131.3(\mathrm{C}), 129.0(\mathrm{CH}), 128.4(\mathrm{CH}), 127.6(\mathrm{C})$, $127.1(\mathrm{C}), 126.7(\mathrm{CH}), 125.4(\mathrm{CH}), 123.5(\mathrm{C}), 123.1(\mathrm{CH}), 121.8(\mathrm{CH}), 121.2(\mathrm{C}), 119.5(\mathrm{CH})$, $62.7(\mathrm{C}), 61.6\left(\mathrm{CH}_{2}\right), 60.3(\mathrm{CH}), 39.5\left(\mathrm{CH}_{2}\right), 27.1\left(\mathrm{CH}_{2}\right), 22.8\left(\mathrm{CH}_{2}\right), 14.2\left(\mathrm{CH}_{3}\right), 13.6\left(\mathrm{CH}_{3}\right)$; MS(3.5 KV, ESI): $612\left(\mathrm{M}+\mathrm{H}^{+}\right), 634\left(\mathrm{M}+\mathrm{Na}^{+}\right)$; I.R. $\lambda^{-1}$ (nujol): 3354, 1701, 1670, 1603, 1541, $1466,1377,1348,1289,1250,1213,1101,1024$; Elem. Anal.calcld. for $\mathrm{C}_{35} \mathrm{H}_{37} \mathrm{~N}_{3} \mathrm{O}_{7}$ : C 68.72; $\mathrm{H}$ 6.10, N 6.87; found: C $68.91 \mathrm{H} 6.18 \mathrm{~N} 6.73$.

6. M.p.: $127-129^{\circ} \mathrm{C} ;[\alpha]_{\mathrm{D}}{ }^{20}=-46.1\left(c=0.80 \mathrm{CHCl}_{3}\right) ;{ }^{1} \mathrm{H}-\mathrm{NMR}\left(\mathrm{CDCl}_{3}\right)$ : $9.26(\mathrm{~d}, 1 \mathrm{H}, \mathrm{J}=2.0 \mathrm{~Hz})$, $8.71(\mathrm{~d}, 1 \mathrm{H}, \mathrm{J}=2.0 \mathrm{~Hz}), 8.03(\mathrm{~d}, 1 \mathrm{H}, \mathrm{J}=8.4 \mathrm{~Hz}), 7.95(\mathrm{~d}, 1 \mathrm{H}, \mathrm{J}=8.4 \mathrm{~Hz}), 4.43(\mathrm{q}, 2 \mathrm{H}, \mathrm{J}=7.1$ $\mathrm{Hz}), 4.08(\mathrm{dd}, 1 \mathrm{H}, \mathrm{J}=5.6 \mathrm{~Hz}, \mathrm{~J}=9.3 \mathrm{~Hz}), 3.37(\mathrm{td}, 1 \mathrm{H}, \mathrm{J}=6.3 \mathrm{~Hz}, \mathrm{~J}=10.7 \mathrm{~Hz}), 3.15(\mathrm{td}, 1 \mathrm{H}, \mathrm{J}$ $=6.5 \mathrm{~Hz}, \mathrm{~J}=10.7 \mathrm{~Hz}), 2.40-2.23(\mathrm{~m}, 1 \mathrm{H}), 2.19-1.98(\mathrm{~m}, 5 \mathrm{H}), 2.00-1.77(\mathrm{~m}, 2 \mathrm{H}), 1.42(\mathrm{t}, 3 \mathrm{H}, \mathrm{J}=$ $7.1 \mathrm{~Hz}), 1.28-1.12(\mathrm{~m}, 8 \mathrm{H}), 0.79(\mathrm{t}, 6 \mathrm{H}, \mathrm{J}=6.8 \mathrm{~Hz}) ;{ }^{13} \mathrm{C}-\mathrm{NMR}\left(\mathrm{CDCl}_{3}\right): 196.8(\mathrm{C}), 174.8(\mathrm{C})$, 173.3 (C), 172.8 (C), 164.8 (C), 147.3 (C), 142.0 (C), 131.4 (C), 127.7 (C), 127.4 (C), 125.1 (C), $124.1(\mathrm{CH}), 122.4(\mathrm{CH}), 122.1(\mathrm{C}), 121.8(\mathrm{CH}), 121.0(\mathrm{C}), 119.4(\mathrm{CH}), 62.8(\mathrm{C}), 61.8(\mathrm{CH})$, $61.5\left(\mathrm{CH}_{2}\right), 47.5\left(\mathrm{CH}_{2}\right), 39.4\left(\mathrm{CH}_{2}\right), 30.3\left(\mathrm{CH}_{2}\right), 27.0\left(\mathrm{CH}_{2}\right), 24.5(\mathrm{C}), 22.7\left(\mathrm{CH}_{2}\right), 14.2\left(\mathrm{CH}_{3}\right)$, $13.5\left(\mathrm{CH}_{3}\right)$; $\mathrm{MS}(3.5 \mathrm{KV}, \mathrm{ESI}): 576\left(\mathrm{M}+\mathrm{H}^{+}\right), 598\left(\mathrm{M}+\mathrm{Na}^{+}\right)$; I.R. $\lambda^{-1}$ (nujol): 3360, 3221, 1719 , 1676, 1605, 1582, 1528, 1458, 1377, 1285, 1244, 1211, 1098, 1024; Elem. Anal.calcld. for $\mathrm{C}_{32} \mathrm{H}_{37} \mathrm{~N}_{3} \mathrm{O}_{7}$ : C 66.77, $\mathrm{H}$ 6.48, N 7.30; found: C 66.54, H 6.64, N 7.34.

Physical data for receptor 7. M.p.: $176-178^{\circ} \mathrm{C} ;[\alpha]_{\mathrm{D}}{ }^{20}=-16.9\left(c=0.92 \mathrm{CHCl}_{3}\right) ;{ }^{1} \mathrm{H}-\mathrm{NMR}$ $\left(\mathrm{CDCl}_{3}-10 \% \mathrm{CD}_{3} \mathrm{OD}\right): 9.30(\mathrm{~d}, 1 \mathrm{H}, \mathrm{J}=2.1 \mathrm{~Hz}), 8.73(\mathrm{~d}, 1 \mathrm{H}, \mathrm{J}=2.1 \mathrm{~Hz}), 8.04(\mathrm{~d}, 1 \mathrm{H}, \mathrm{J}=8.4 \mathrm{~Hz})$, 
$7.95(\mathrm{~d}, 1 \mathrm{H}, \mathrm{J}=8.4 \mathrm{~Hz}), 4.43(\mathrm{q}, 2 \mathrm{H}, \mathrm{J}=7.2 \mathrm{~Hz}), 4.44-4.36(\mathrm{~m}, 1 \mathrm{H}), 3.74-3.60(\mathrm{~m}, 1 \mathrm{H}), 3.26-3.18$ $(\mathrm{m}, 1 \mathrm{H}), 2.71(\mathrm{~s}, 3 \mathrm{H}), 2.73-2.61(\mathrm{~m}, 2 \mathrm{H}), 2.48-2.34(\mathrm{~m}, 2 \mathrm{H}), 2.18-1.90(\mathrm{~m}, 4 \mathrm{H}), 1.42(\mathrm{t}, 3 \mathrm{H}, \mathrm{J}=$ 7.2Hz), 1.33-1.15 (m, 8H), 0.83-0.74 (m, 6H); ${ }^{13} \mathrm{C}-\mathrm{NMR}\left(\mathrm{CDCl}_{3}\right): 196.5(\mathrm{C}), 175.5(\mathrm{C}), 174.8$ (C), 173.1 (C), 172.4 (C), 164.7 (C), 147.4 (C), 143.2 (C), 142.0 (C), 131.2 (C), 127.4 (C), 124.8 $(\mathrm{CH}), 122.6(\mathrm{CH}), 122.2(\mathrm{C}), 121.8(\mathrm{CH}), 121.2(\mathrm{C}), 119.5(\mathrm{CH}), 70.2(\mathrm{CH}), 62.8(\mathrm{C}), 61.5$ $\left(\mathrm{CH}_{2}\right), 56.7\left(\mathrm{CH}_{2}\right), 42.3\left(\mathrm{CH}_{3}\right), 39.2\left(\mathrm{CH}_{2}\right), 30.8\left(\mathrm{CH}_{2}\right), 27.1\left(\mathrm{CH}_{2}\right), 24.7\left(\mathrm{CH}_{2}\right), 22.7\left(\mathrm{CH}_{3}\right), 14.1$ $\left(\mathrm{CH}_{3}\right), 13.4\left(\mathrm{CH}_{3}\right)$; $\mathrm{MS}(3.5 \mathrm{KV}, \mathrm{ESI}): 590\left(\mathrm{M}+\mathrm{H}^{+}\right), 612\left(\mathrm{M}+\mathrm{Na}^{+}\right)$; I.R. $\lambda^{-1}$ (nujol): 3383, 3239, $1715,1674,1630,1605,1522,1464,1377,1281,1211,1161,1024$. Elem. Anal.calcld. for $\mathrm{C}_{33} \mathrm{H}_{39} \mathrm{~N}_{3} \mathrm{O}_{7}$ : C 67.22, H 6.67, N 7.13; found: C 67.09, H 6.81, N 6.95.

Physical data for receptor 8. M.p.: 204-206 ${ }^{\circ} \mathrm{C}$; $\mathrm{H}-\mathrm{NMR}\left(\mathrm{CDCl}_{3}-5 \% \mathrm{CD}_{3} \mathrm{OD}\right)$ : 9.62 (d, $1 \mathrm{H}, \mathrm{J}$ $=1.9 \mathrm{~Hz}), 8.67(\mathrm{~d}, 1 \mathrm{H}, \mathrm{J}=1.9 \mathrm{~Hz}), 8.00(\mathrm{~d}, 1 \mathrm{H}, \mathrm{J}=8.4 \mathrm{~Hz}), 7.92(\mathrm{~d}, 1 \mathrm{H}, \mathrm{J}=8.4 \mathrm{~Hz}), 4.41(\mathrm{q}, 2 \mathrm{H}, \mathrm{J}$ $=7.1 \mathrm{~Hz}), 3.63(\mathrm{~d}, 1 \mathrm{H}, \mathrm{J}=12.1 \mathrm{~Hz}), 3.32(\mathrm{~d}, 1 \mathrm{H}, \mathrm{J}=11.5 \mathrm{~Hz}), 3.09(\mathrm{~d}, 2 \mathrm{H}, \mathrm{J}=12.0 \mathrm{~Hz}), 2.87-2.78$ $(\mathrm{m}, 1 \mathrm{H}), 2.23-1.65(\mathrm{~m}, 8 \mathrm{H}), 1.42(\mathrm{t}, 3 \mathrm{H}, \mathrm{J}=7.1 \mathrm{~Hz}), 1.31-1.06(\mathrm{~m}, 8 \mathrm{H}), 0.79(\mathrm{t}, 6 \mathrm{H}, \mathrm{J}=$ 6.5Hz); ${ }^{13} \mathrm{C}-\mathrm{NMR}\left(\mathrm{CDCl}_{3}\right): 196.7(\mathrm{C}), 174.9$ (C), 174.2 (C), 164.9 (C), 162.3 (C), 146.7 (C), $142.4(\mathrm{C}), 135.6(\mathrm{C}), 131.4(\mathrm{C}), 128.3(\mathrm{C}), 127.7(\mathrm{C}), 125.2(\mathrm{CH}), 124.8(\mathrm{C}), 122.1(\mathrm{CH}), 121.6$ $(\mathrm{CH}), 121.0(\mathrm{C}), 119.4(\mathrm{CH}), 62.7(\mathrm{C}), 61.4\left(\mathrm{CH}_{2}\right), 47.4\left(\mathrm{CH}_{2}\right), 46.4\left(\mathrm{CH}_{2}\right), 41.7(\mathrm{CH}), 39.5$ $\left(\mathrm{CH}_{2}\right), 39.0\left(\mathrm{CH}_{2}\right), 27.5\left(\mathrm{CH}_{2}\right), 27.1\left(\mathrm{CH}_{2}\right), 22.8\left(\mathrm{CH}_{2}\right), 22.0\left(\mathrm{CH}_{2}\right), 14.1\left(\mathrm{CH}_{3}\right), 13.4\left(\mathrm{CH}_{3}\right)$; MS(3.5 KV, ESI): $590\left(\mathrm{M}+\mathrm{H}^{+}\right)$; I.R. $\lambda^{-1}$ (nujol): 3295, 3204, 2926, 2855, 1703, 1672, 1630, $1605,1582,1549,1464,1377,1289,1250,1213,1159,1105,1071,1024$. Elem. Anal.calcd. for $\mathrm{C}_{33} \mathrm{H}_{39} \mathrm{~N}_{3} \mathrm{O}_{7}$ : C 67.22, H 6.67, N 7.13; found: C 67.14, H 6.59, N 7.24.

Physical data for receptor 9. M.p.: $210-212{ }^{\circ} \mathrm{C} ;{ }^{1} \mathrm{H}-\mathrm{NMR}\left(\mathrm{CDCl}_{3}-5 \% \mathrm{CD}_{3} \mathrm{OD}\right): 9.15$ (d, $1 \mathrm{H}, \mathrm{J}$ $=2.0 \mathrm{~Hz}), 8.72(\mathrm{~d}, 1 \mathrm{H}, \mathrm{J}=2.0 \mathrm{~Hz}), 8.01(\mathrm{~d}, 1 \mathrm{H}, \mathrm{J}=8.4 \mathrm{~Hz}), 7.93(\mathrm{~d}, 1 \mathrm{H}, \mathrm{J}=8.4 \mathrm{~Hz}), 4.41(\mathrm{q}, 2 \mathrm{H}, \mathrm{J}$ $=7.1 \mathrm{~Hz}), 3.62-3.54(\mathrm{~m}, 1 \mathrm{H}), 3.18-3.09(\mathrm{~m}, 1 \mathrm{H}), 2.94-2.89(\mathrm{~m}, 1 \mathrm{H}), 2.56-2.33(\mathrm{~m}, 5 \mathrm{H}), 2.22-1.73$ $(\mathrm{m}, 8 \mathrm{H}), 1.42(\mathrm{t}, 3 \mathrm{H}, \mathrm{J}=7.1 \mathrm{~Hz}), 1.29-1.03(\mathrm{~m}, 8 \mathrm{H}), 0.76(\mathrm{t}, 6 \mathrm{H}, \mathrm{J}=6.2 \mathrm{~Hz}) ;{ }^{13} \mathrm{C}-\mathrm{NMR}\left(\mathrm{CDCl}_{3}\right)$ : 196.8 (C), 175.0 (C), 174.4 (C), 173.6 (C), 164.7 (C), 148.5 (C), 142.5 (C), 131.3 (C), 128.1 (C), $127.7(\mathrm{C}), 127.3(\mathrm{C}), 125.3(\mathrm{CH}), 123.5(\mathrm{CH}), 122.2(\mathrm{C}), 121.8(\mathrm{CH}), 121.5(\mathrm{C}), 119.6(\mathrm{CH})$, $62.6(\mathrm{C}), 61.5\left(\mathrm{CH}_{2}\right), 57.5\left(\mathrm{CH}_{2}\right), 55.6\left(\mathrm{CH}_{2}\right), 46.1\left(\mathrm{CH}_{3}\right), 42.4(\mathrm{CH}), 39.5\left(\mathrm{CH}_{2}\right), 39.2\left(\mathrm{CH}_{2}\right)$, $27.1\left(\mathrm{CH}_{2}\right), 26.2\left(\mathrm{CH}_{2}\right), 22.7\left(\mathrm{CH}_{2}\right), 14.1\left(\mathrm{CH}_{3}\right), 13.5\left(\mathrm{CH}_{3}\right) ; \mathrm{MS}(3.5 \mathrm{KV}, \mathrm{ESI}): 604\left(\mathrm{M}+\mathrm{H}^{+}\right)$, $626\left(\mathrm{M}+\mathrm{Na}^{+}\right.$); I.R. $\lambda^{-1}$ (nujol): 3374, 3187, 3127, 1713, 1678, 1601, 1580, 1534, 1464, 1377 , 1287, 1250, 1219, 1144, 1067, 1024. Elem. Anal.calcld. for $\mathrm{C}_{34} \mathrm{H}_{41} \mathrm{~N}_{3} \mathrm{O}_{7}: \mathrm{C} 67.64, \mathrm{H} \mathrm{6.85,} \mathrm{N}$ 6.96; found: C 67.70, H 6.79, N 7.01.

Preparation of receptors 10 to 14. The xanthone amine derivative $16(1.0 \mathrm{~g}, 2.1 \mathrm{mmol})$ was dissolved in dry $\mathrm{CH}_{2} \mathrm{Cl}_{2}(20.0 \mathrm{ml})$ and an excess of a $0.6 \mathrm{M}$ solution of phosgene in toluene (2.0 $\mathrm{ml}$ ) was added. Then, the reaction mixture was refluxed, and after 30 minutes the solvent and the excess phosgene were evaporated off under reduced pressure.

Then, the isocyanate was dissolved in toluene $(40.0 \mathrm{ml})$ and a $0.15 \mathrm{M}$ solution of the ethylene diamine derivative (receptors $\mathbf{1 0}$ to 13$)$ in toluene $(40.0 \mathrm{ml})$ or $0.06 \mathrm{M}$ of the phenylglycinol (receptor 14$)$ in toluene $(40.0 \mathrm{ml})$ was added dropwise for 10 minutes at room temperature. The reaction mixture was first washed with $0.2 \mathrm{M} \mathrm{HCl}$ and then with $4 \% \mathrm{Na}_{2} \mathrm{CO}_{3}$. The desired receptor was recovered after evaporation of the solvent. The receptors were 
crystallized in a 9/1 ether/methylene chloride mixture. Silica gel cromatography was required to purify receptor 11 because some of its regioisomer was generated. Yields with respect to xanthone amine derivative: receptor 10: $95 \%,(1.13 \mathrm{~g})$; receptor 11: 58\%, $(0.71 \mathrm{~g})$; receptor 12: 93\%, (1.40 g); receptor 13: 95\%, (1.23 g); receptor 14: 94\%, (1.47 g).

Physical data for receptor 10. M.p.: $234-236{ }^{\circ} \mathrm{C} ;{ }^{1} \mathrm{H}-\mathrm{NMR}\left(\mathrm{CDCl}_{3}\right): 9.17(\mathrm{~d}, 1 \mathrm{H}, \mathrm{J}=2.0 \mathrm{~Hz})$, $8.54(\mathrm{~d}, 1 \mathrm{H}, \mathrm{J}=2.0 \mathrm{~Hz}), 7.96(\mathrm{~d}, 1 \mathrm{H}, \mathrm{J}=8.4 \mathrm{~Hz}), 7.89(\mathrm{~d}, 1 \mathrm{H}, \mathrm{J}=8.4 \mathrm{~Hz}), 4.36(\mathrm{q}, 2 \mathrm{H}, \mathrm{J}=7.0$ $\mathrm{Hz}), 3.56-3.44$ (m, 2H), 3.32-3.22 (m, 2H), 2.03-1.89 (m, 4H), 1.37 (t, 3H, J = 7.0 Hz), 1.24-0.99 $(\mathrm{m}, 8 \mathrm{H}), 0.79-0.64(\mathrm{~m}, 6 \mathrm{H}) ;{ }^{13} \mathrm{C}-\mathrm{NMR}\left(\mathrm{CDCl}_{3}\right)$ : $197.7(\mathrm{C}), 175.6(\mathrm{C}), 174.9(\mathrm{C}), 165.4(\mathrm{C})$, 156.3 (C), 147.6 (C), 143.5 (C), 132.5 (C), 129.7 (C), 126.8 (C), 125.3 (C), 124.3 (CH), 122.3 (C), $121.5(\mathrm{CH}), 121.1(\mathrm{C}), 120.4(\mathrm{CH}), 119.0(\mathrm{CH}), 62.1(\mathrm{C}), 61.3\left(\mathrm{CH}_{2}\right), 40.2\left(\mathrm{CH}_{2}\right), 39.2$ $\left.\left(\mathrm{CH}_{2}\right), 29.4\left(\mathrm{CH}_{2}\right), 26.8\left(\mathrm{CH}_{2}\right), 22.6\left(\mathrm{CH}_{2}\right), 13.9\left(\mathrm{CH}_{3}\right), 13.2\left(\mathrm{CH}_{3}\right) ;\right)$; $\mathrm{MS}(3.5 \mathrm{KV}, \mathrm{ESI}): 565$ $\left(\mathrm{M}+\mathrm{H}^{+}\right), 587\left(\mathrm{M}+\mathrm{Na}^{+}\right)$; I.R. $\lambda^{-1}$ (nujol): 3318, 1703, 1670, 1578, 1551, 1462, 1377, 1289, 1244, 1213, 1026; Elem. Anal.calcld. for $\mathrm{C}_{30} \mathrm{H}_{36} \mathrm{~N}_{4} \mathrm{O}_{7}$ : C 63.82, H 6.43, N 9.92; found: C 63.78, H 6.28, N 9.77 .

Physical data for receptor 11. M.p.: $150-152^{\circ} \mathrm{C} ;[\alpha]_{\mathrm{D}}{ }^{20}=+16.7\left(c=0.71 \mathrm{CHCl}_{3}\right)$; ${ }^{1} \mathrm{H}-\mathrm{NMR}$ $\left(\mathrm{CDCl}_{3}\right): 9.25(\mathrm{~d}, 1 \mathrm{H}, \mathrm{J}=2.1 \mathrm{~Hz}), 8.58(\mathrm{~d}, 1 \mathrm{H}, \mathrm{J}=2.1 \mathrm{~Hz}), 7.99(\mathrm{~d}, 1 \mathrm{H}, \mathrm{J}=8.4 \mathrm{~Hz}), 7.91(\mathrm{~d}, 1 \mathrm{H}$, $\mathrm{J}=8.4 \mathrm{~Hz}), 4.38(\mathrm{q}, 2 \mathrm{H}, \mathrm{J}=7.1 \mathrm{~Hz}), 3.46(\mathrm{dd}, 1 \mathrm{H}, \mathrm{J}=2.5 \mathrm{~Hz}, \mathrm{~J}=12.9 \mathrm{~Hz}), 3.48-3.19(\mathrm{~m}, 1 \mathrm{H})$, $3.12(\mathrm{dd}, 1 \mathrm{H}, \mathrm{J}=8.1 \mathrm{~Hz}, \mathrm{~J}=12.9 \mathrm{~Hz}), 2.04-1.88(\mathrm{~m}, 4 \mathrm{H}), 1.39(\mathrm{t}, 3 \mathrm{H}, \mathrm{J}=7.1 \mathrm{~Hz}), 1.26-1.03(\mathrm{~m}$, $11 \mathrm{H}), 0.75(\mathrm{t}, 6 \mathrm{H}, \mathrm{J}=6.6 \mathrm{~Hz}) ;{ }^{13} \mathrm{C}-\mathrm{NMR}\left(\mathrm{CDCl}_{3}\right)$ : $196.6(\mathrm{C}), 175.0(\mathrm{C}), 164.9$ (C), 157.1 (C), 156.6 (C), 147.5 (C), 143.0 (C), 131.6 (C), 129.2 (C), 127.2 (C), $125.3(\mathrm{C}), 125.0(\mathrm{CH}), 122.3$ (C), $121.8(\mathrm{CH}), 121.3(\mathrm{CH}), 120.8(\mathrm{C}), 119.6(\mathrm{CH}), 62.5(\mathrm{C}), 61.4\left(\mathrm{CH}_{2}\right), 47.9(\mathrm{CH}), 39.1(\mathrm{CH})$, $38.7\left(\mathrm{CH}_{2}\right), 27.0\left(\mathrm{CH}_{2}\right), 22.8\left(\mathrm{CH}_{2}\right), 20.6\left(\mathrm{CH}_{3}\right), 14.2\left(\mathrm{CH}_{3}\right), 13.4\left(\mathrm{CH}_{3}\right) ; \mathrm{MS}(3.5 \mathrm{KV}, \mathrm{ESI}): 579$ $\left(\mathrm{M}+\mathrm{H}^{+}\right), 601\left(\mathrm{M}+\mathrm{Na}^{+}\right)$; I.R. $\lambda^{-1}$ (nujol): 3343, 1705, 1670, 1601, 1549, 1464, 1377, 1352, 1292, 1246, 1217, 1103, 1028; Elem. Anal.calcld. for $\mathrm{C}_{31} \mathrm{H}_{38} \mathrm{~N}_{4} \mathrm{O}_{7}$ : C 64.34, H 6.62, N 9.68; found: C 64.17, H 6.47, N 9.75.

Physical data for receptor 12. M.p.: $151-153^{\circ} \mathrm{C} ;[\alpha]_{\mathrm{D}}{ }^{20}=-55.5\left(c=1.27 \mathrm{CHCl}_{3}\right)$; ${ }^{1} \mathrm{H}-\mathrm{NMR}$ $\left(\mathrm{CDCl}_{3}-5 \% \mathrm{CD}_{3} \mathrm{OD}\right): 9.21(\mathrm{~d}, 1 \mathrm{H}, \mathrm{J}=2.1 \mathrm{~Hz}), 8.57(\mathrm{~d}, 1 \mathrm{H}, \mathrm{J}=2.1 \mathrm{~Hz}), 8.01(\mathrm{~d}, 1 \mathrm{H}, \mathrm{J}=8.4 \mathrm{~Hz})$, $7.93(\mathrm{~d}, 1 \mathrm{H}, \mathrm{J}=8.4 \mathrm{~Hz}), 7.36-7.18(\mathrm{~m}, 10 \mathrm{H}), 5.22(\mathrm{~d}, 1 \mathrm{H}, \mathrm{J}=6.1 \mathrm{~Hz}), 4.40(\mathrm{~d}, 1 \mathrm{H}, \mathrm{J}=6.1 \mathrm{~Hz})$, 4.35 (q, 2H, J = 7.1Hz), 2.15-1.96 (m, 4H), $1.36(\mathrm{t}, 3 \mathrm{H}, \mathrm{J}=7.1 \mathrm{~Hz}), 1.27-1.04(\mathrm{~m}, 8 \mathrm{H}), 0.85-0.72$ $(\mathrm{m}, 6 \mathrm{H}) ;{ }^{13} \mathrm{C}-\mathrm{NMR}\left(\mathrm{CDCl}_{3}\right)$ : 196.9 (C), 175.6 (C), 175.3 (C), 174.8 (C), 165.3 (C), 155.7 (C), 147.7 (C), 143.3 (C), 139.0 (C), 138.3 (C), 136.4 (C), 132.1 (C), 129.4 (C), 128.5 (CH), 127.8 $(\mathrm{CH}), 127.1(\mathrm{CH}), 125.3(\mathrm{CH}), 122.5(\mathrm{C}), 121.8(\mathrm{CH}), 121.3(\mathrm{CH}), 119.3(\mathrm{CH}), 62.4(\mathrm{C}), 61.5$ $\left(\mathrm{CH}_{2}\right), 60.6(\mathrm{CH}), 59.8(\mathrm{CH}), 38.4\left(\mathrm{CH}_{2}\right), 26.9\left(\mathrm{CH}_{2}\right), 22.9\left(\mathrm{CH}_{2}\right), 14.2\left(\mathrm{CH}_{3}\right), 13.5\left(\mathrm{CH}_{3}\right)$; MS(3.5 KV, ESI): $717\left(\mathrm{M}+\mathrm{H}^{+}\right), 739\left(\mathrm{M}+\mathrm{Na}^{+}\right)$; I.R. $\lambda^{-1}$ (nujol): 3360, 1707, 1670, 1603, 1582, $1541,1458,1377,1289,1244,1213,1099,1026$. Elem. Anal.calcld. for $\mathrm{C}_{42} \mathrm{H}_{44} \mathrm{~N}_{4} \mathrm{O}_{7}$ : C 70.37, $\mathrm{H}$ 6.19, N 7.82; found: C 70.22, H 6.11, N 7.83.

Physical data for receptor 13. M.p.: $158-160^{\circ} \mathrm{C} ;[\alpha]_{\mathrm{D}}{ }^{20}=-6.6\left(c=0.77 \mathrm{CHCl}_{3}\right)$; ${ }^{1} \mathrm{H}-\mathrm{NMR}$ $\left(\mathrm{CDCl}_{3}\right): 9.26(\mathrm{~d}, 1 \mathrm{H}, \mathrm{J}=2.0 \mathrm{~Hz}), 8.54(\mathrm{~d}, 1 \mathrm{H}, \mathrm{J}=2.0 \mathrm{~Hz}), 7.97(\mathrm{~d}, 1 \mathrm{H}, \mathrm{J}=8.4 \mathrm{~Hz}), 7.89(\mathrm{~d}, 1 \mathrm{H}$, $\mathrm{J}=8.5 \mathrm{~Hz}), 4.36(\mathrm{q}, 2 \mathrm{H}, \mathrm{J}=7.1 \mathrm{~Hz}), 2.59-2.44(\mathrm{~m}, 1 \mathrm{H}), 2.38-2.26(\mathrm{~m}, 1 \mathrm{H}), 2.08-1.93(\mathrm{~m}, 6 \mathrm{H})$, $1.78-1.70(\mathrm{~m}, 2 \mathrm{H}), 1.36(\mathrm{t}, 3 \mathrm{H}, \mathrm{J}=7.1 \mathrm{~Hz}), 1.32-0.99(\mathrm{~m}, 12 \mathrm{H}), 0.73(\mathrm{t}, 6 \mathrm{H}, \mathrm{J}=6.6 \mathrm{~Hz}) ;{ }^{13} \mathrm{C}-$ 
NMR ( $\left.\mathrm{CDCl}_{3}\right)$ : 196.9 (C), $175.0(\mathrm{C}), 174.5$ (C), 164.8 (C), $156.6(\mathrm{C}), 147.1(\mathrm{C}), 142.8$ (C), 131.8 (C), $129.4(\mathrm{C}), 127.3(\mathrm{C}), 125.2(\mathrm{C}), 124.5(\mathrm{CH}), 122.1(\mathrm{C}), 121.7(\mathrm{CH}), 121.1(\mathrm{C}), 120.6(\mathrm{CH})$, $119.3(\mathrm{CH}), 62.4(\mathrm{C}), 61.2\left(\mathrm{CH}_{2}\right), 58.6(\mathrm{CH}), 56.8(\mathrm{CH}), 38.9\left(\mathrm{CH}_{2}\right), 33.8\left(\mathrm{CH}_{2}\right), 32.3\left(\mathrm{CH}_{2}\right)$, $27.0\left(\mathrm{CH}_{2}\right), 25.1\left(\mathrm{CH}_{2}\right), 24.5\left(\mathrm{CH}_{2}\right), 22.7\left(\mathrm{CH}_{2}\right), 14.1\left(\mathrm{CH}_{3}\right), 13.5\left(\mathrm{CH}_{3}\right) ; \mathrm{MS}(3.5 \mathrm{KV}, \mathrm{ESI}): 619$ $\left(\mathrm{M}+\mathrm{H}^{+}\right), 641\left(\mathrm{M}+\mathrm{Na}^{+}\right)$; I.R. $\lambda^{-1}$ (nujol): 3343, 1709, 1669, 1601, 1549, 1462, 1377, 1287, 1211, 1099, 1024; Elem. Anal.calcld. for $\mathrm{C}_{34} \mathrm{H}_{42} \mathrm{~N}_{4} \mathrm{O}_{7}$ : C 66.00, H 6.84, N 9.06; found: C 65.82, H 7.01, N 8.95.

Physical data for receptor 14. M.p.: $240-242^{\circ} \mathrm{C} ;[\alpha]_{\mathrm{D}}{ }^{20}=-50.0(c=0.70$ DMSO $) ;{ }^{1} \mathrm{H}-\mathrm{NMR}$ $\left(\mathrm{CDCl}_{3}\right): 9.29(\mathrm{~d}, 1 \mathrm{H}, \mathrm{J}=1.8 \mathrm{~Hz}), 8.52(\mathrm{~d}, 1 \mathrm{H}, \mathrm{J}=1.8 \mathrm{~Hz}), 7.97(\mathrm{~d}, 1 \mathrm{H}, \mathrm{J}=8.4 \mathrm{~Hz}), 7.89(\mathrm{~d}, 1 \mathrm{H}, \mathrm{J}$ $=8.4 \mathrm{~Hz}), 7.387 .24(\mathrm{~m}, 5 \mathrm{H}), 6.87(\mathrm{~d}, 1 \mathrm{H}, \mathrm{J}=5.9 \mathrm{~Hz}), 5.00-4.88(\mathrm{~m}, 1 \mathrm{H}), 4.32(\mathrm{q}, 2 \mathrm{H}, \mathrm{J}=7.1 \mathrm{~Hz})$, $3.91(\mathrm{dd}, 1 \mathrm{H}, \mathrm{J}=3.9 \mathrm{~Hz}, \mathrm{~J}=11.3 \mathrm{~Hz}), 3.76(\mathrm{dd}, 1 \mathrm{H}, \mathrm{J}=7.1 \mathrm{~Hz}, \mathrm{~J}=11.3 \mathrm{~Hz}), 2.08-1.91(\mathrm{~m}, 4 \mathrm{H})$, $1.33(\mathrm{t}, 3 \mathrm{H}, \mathrm{J}=7.1 \mathrm{~Hz}), 1.22-1.03(\mathrm{~m}, 8 \mathrm{H}), 0.72(\mathrm{t}, 6 \mathrm{H}, \mathrm{J}=6.5 \mathrm{~Hz}) ;{ }^{13} \mathrm{C}-\mathrm{NMR}\left(\mathrm{DMSO}_{6}\right): 197.2$ (C), 175.0 (C), 173.4 (C), 164.6 (C), 154.2 (C), 147.2 (C), 143.3 (C), 141.4 (C), 132.5 (C), 130.3 (C), $128.1(\mathrm{CH}), 126.7(\mathrm{CH}), 125.9(\mathrm{C}), 125.2(\mathrm{CH}), 124.9(\mathrm{C}), 123.1(\mathrm{CH}), 121.5(\mathrm{C}), 121.0$ $(\mathrm{CH}), 120.7(\mathrm{C}), 118.5(\mathrm{CH}), 118.3(\mathrm{CH}), 72.1(\mathrm{C}), 64.4\left(\mathrm{CH}_{2}\right), 61.4\left(\mathrm{CH}_{2}\right), 55.3(\mathrm{CH}), 29.9$ $\left(\mathrm{CH}_{2}\right), 26.5\left(\mathrm{CH}_{2}\right), 22.3\left(\mathrm{CH}_{2}\right), 14.1\left(\mathrm{CH}_{3}\right), 13.4\left(\mathrm{CH}_{3}\right) ; \mathrm{MS}(3.5 \mathrm{KV}, \mathrm{ESI}):$ 648( $\left(\mathrm{M}^{2} \mathrm{Li}^{+}\right)$, 664(M+Na ${ }^{+}$); I.R. $\lambda^{-1}$ (nujol): 3488, 3378,3302, 3255, 2920, 2855, 1890, 1705, 1678, 1626, $1562,1468,1377,1348,1289,1250,1223,1078,1026$; Elem. Anal.calcld. for $\mathrm{C}_{36} \mathrm{H}_{39} \mathrm{~N}_{3} \mathrm{O}_{8}$ : C 67.38, H 6.13, N 6.55; found: C 67.58, H 6.05, N 6.36.

\section{$\underline{\text { Supplementary Information Available }}$}

Cartesian atomic coordinates of the calculated structures. Competitive titration curves. Graphic plots of the lactam 1 concentration vs. time for the kinetic experiments. Deconvoluted spectra for the determination of chiral assistance. Circular dichroism of thiol product obtained in the reaction catalyzed by receptor D-6.

\section{Acknowledgements}

We thank the DGICYT (CTQ-2005-074007bqu) and the JCL (SA 52/03) for their support in this work. The MEC is acknowledged for three fellowships (L.S., F.M.M., S.S.). We thank Anna Lithgow for the NMR spectra. 


\section{References and Footnotes}

1. (a) Cleland, W. W.; Kreevoy, M. M. Science 1994, 264, 1887. (b) Nardini, M.; Dijkstra, B. W. Curr. Op. Struct. Biol. 1999, 9, 732. (c) Verschueren, K. H. G.; Seljée, F.; Rozeboom, H. J.; Kalk, K. H.; Dijkstra, B. W. Nature 1993, 363, 693. (d) Harel, M.; Quinn, D. M.; Nair, H. K.; Silman, I.; Sussman, J. L. J. Am. Chem. Soc. 1996, 118, 2340. (e) Hermann, J. C.; Ridder, L.; Mulholland, A. J.; Höltje, H. D. J. Am. Chem. Soc. 2003, 125, 9590. (f) Frey, P. A.; Whitt, S. A.; Tobin, J. B. Science 1994, 264, 1927. (g) Line, K.; Isupov, M. N.; Littlechild, J. A. J. Mol. Biol. 2004, 338, 519.

2. Thayer, M. M.; Olender, E. H.; Arvai, A. S.; Koike, C. K.; Canestrelli, I. L.; Stewart, J. D.; Benkovic, S. J.; Getzoff, E. D.; Roberts, V. A. J. Mol. Biol. 1999, $291,329$.

3. (a) Bahnson, B. J.; Anderson, V. E.; Petsko, G. A. Biochemistry 2002, 41, 2621. (b) Pawlak, J.; Bahnson, B. J.; Anderson, V. E. Nukleonika 2002, 47 (Suppl. 1), 115.

4. Fulbini, B.; Otero Aldeán, C. Chem. Soc. Rev. 1999, 28, 373.

5. For recent reviews, see for example: (a) Dalko, P. I.; Moisan, L. Angew. Chem. Int. Ed. 2001, 40, 3726. (b) Houk, K. N.; List, B. Acc. Chem. Res., 2004, 37, 487, and next articles in this number of Accounts of Chemical Research. (c) Asymmetric Organocatalysis, from Biomimetic concepts to Applications in Asymmetric Synthesis, Berkessel, A.; Gröguer, H. Wiley-VCH, Weinheim 2005.

6. For recent works and reviews on this field: (a) Schreiner, P. R. Chem. Soc. Rev. 2003, 32, 289. (b) Pihko, P. M. Angew. Chem. Int. Ed. 2004, 43, 2062. (c) Fuerst, D. E.; Jacobsen, E. N. 2005, J. Am. Chem. Soc., 127, 8964. (d) Okino, T.; Hoashi, Y.; Takemoto, Y. J. Am. Chem. Soc. 2003, 125, 12672. (e) Martín-Portugués, M.; Alcázar, V.; Prados, P.; Mendoza J. Tetrahedron 2002, 58, 2951. (f) Snowden, T. S.; Bisson, A. P.; Anslyn, E. V. Bioorg. Med. Chem. 2001, 9, 2467. (g) Rajaram, S.; Sigman, M. S. Org. Lett. 2005, 7, 5473. (h) Motherwell, W. B.; Bingham, M. J.; Six Y. Tetrahedron 2001, 57, 4663. (i) Zhuang, W.; Poulsen, T. B.; Jørgensen, K. A. Org. Biomol. Chem. 2005, 3, 3284. (j) Ortega-Caballero, F.; Bjerre, J.; Laustsen, L. S.; Bols, M. J. Org. Chem. 2005, 70, 7217. (k) Wenzel, A. G.; Jacobsen, E. N. J. Am. Chem. Soc. 2002, 124, 12964. (1) Vachal, P.; Jacobsen, E. N. J. Am. Chem. Soc., 2002, 124, 10012. (m) Sigman, M. S.; Vachal, P.; Jacobsen, E. N.; Angew. Chem. Int. Ed. 2000, 39, 1279. (n) Sigman, M. S.; Jacobsen, E. N. J. Am. Chem. Soc., 120, 4901-4902, 1998. (o) Curran, D. P.; Kuo, L. H. Tetrahedron Lett. 1995, 36, 6647. (p) Dove, A. P.; Pratt, R. C.; Lohmeifer, B. G. G.; Waymouth, R. M.; Hedrick, J. L.; J. Am. Chem. Soc., 2005, 127, 13798.

7. Hiemstra, H.; Wynberg H. J. Am. Chem. Soc. 1981, 103, 417.

8. Faber, W. S.; Kok, J.; de Lange, B.; Feringa, B.L. Tetrahedron 1994, 50, 4775.

9. (a) Crego, M.; Raposo, C.; Mussons, M. L.; Caballero, M. C.; Morán, J. R. Tetrahedron Lett. 1994, 35, 1929. (b) Crego, M.; Raposo, C.; Mussons, M. L.; Berrocal, A.; Caballero, M. C.; Morán, J. R. Heterocycles 1995, 40, 139. (c) Simón, L.; Muñiz, F. M.; Sáez S.; Raposo C.; Sanz, F.; Morán J. R. Helv. Chim. Acta 2005, 88, 1682. 
10. Gaussian 98 (Revision A.1.0), Frisch, M. J.; Trucks, G. W.; Schlegel, H. B.; Scuseria, G. E.; Robb, M. A.; Cheeseman, J. R.; Zakrzewski, V. G.; Montgomery, J. A.; Stratmann, R. E.; Burant, J. C.; Dapprich, S. et al Gaussian, Inc., Pittsburgh PA, 1998.

11. (a) Miertus, S.; Scrocco E.; Tomasi J. J. Chem. Phys. 1981, 55, 117. (b) Miertus, S.; Tomasi, J. J. Chem. Phys. 1982, 65, 239. (c) Cances, E.; Mennucci, B.; Tomasi, J. J. Chem. Phys. 1997, 107, 3032. (d) Barone, V.; Cossi, M.; Mennucci, B.; Tomasi, J. J. Chem. Phys. 1997, 107, 3210. (e) Tomasi, J.; Mennucci B.; Cammi R., Chem. Rev. 2005, 105, 2999.

12. (a) Pardo, L.; Osman, R.; Weinstein, H.; Rabinowitz, J. R. J. Am. Chem. Soc. 1993, 115, 8263. (b) Lin X., Zhao C., Phillips D. L., J.Org.Chem. 2005, 70, 9279.

13. (a) Bruice, P. Y.; Bruice, T. C. J. Am. Chem. Soc. 1974, 96, 5523. (b) Bruice, P. Y.; Bruice, T. C. J. Am. Chem. Soc. 1974, 96, 5533. (c) Adalsteinsson, H.; Bruice, T. C. J. Am. Chem. Soc. 1998, 120, 3440.

14. Breneman, C. M.; Wiberg, K. B. J. Comp. Chem. 1990, 11, 361.

15. Feelding L., Tetrahedron 2000, 56, 6151.

16. Gaussian deconvolution was performed using Mestre-C software. For more information: Cobas, J. C.; Sardina, F. J. Concept. Magn. Reson. 2003, 19A, 80.

17. (a) Takayanagi, H.; Ogura, H. Croat. Chem. Acta 1989, 62, 135. (b) Barth, G.; Voelter, W.; Mosher, H. S.; Bunnenberg, E.; Djerassi, C. J. Am. Chem. Soc. 1970, 92, 875.

18. (a) Humbel, S.; Sieber, S.; Morokuma, K. J. Chem. Phys. 1996, 105, 1959. (b) Maseras, F.; Morokuma, K. J. Comp. Chem. 1995, 16, 1170. (c) Matsubara, T.; Sieber S.; Morokuma, K. Int. J. Quantum Chem. 1996, 60, 1101. (d) Svensson, M.; Humbel, S.; Froese, R. D. J.; Matsubara, T.; Sieber, S.; Morokuma, K. J. Phys. Chem. 1996, 100, 19357.

19. (a) Lo, Y.C.; Lin, S.C.; Shaw, J. F.; Liaw, Y. C. J. Mol. Biol. 2003, 330, 539. (b) Zhu, X.; Larsen, N. A.; Basran, A.; Bruce, N. C.; Wilson, I. A. J. Biol. Chem. 2003, 278, 2008. (c) Nachon, F.; Asojo, O. A.; Borgstahl, G. E. O.; Masson, P.; Lockridge, O. Biochemistry 2005, 44, 1154. (d) Zhang, Y.; Kua, J.; McCammon, J. A. J. Am. Chem. Soc. 2002, 124, 10572 . 